\title{
Palynology of the uppermost Lower to Middle Jurassic strata on Bornholm, Denmark
}

\author{
TORSTEN HOELSTAD
}

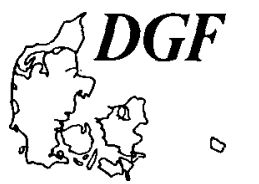

\begin{abstract}
Hoelstad, T.: Palynology of the uppermost Lower to Middle Jurassic strata on Bornholm, Denmark. Bull. geol. Soc. Denmark. vol. 34, pp. 111-132, Copenhagen, December, 19th, 1985. https://doi.org/10.37570/bgsd-1985-34-11

The lithology and palynology of a section, 103 metres thick, from Bagågraven clay pit on Bornholm, Denmark is recorded, and an environmental interpretation is proposed

70 spore-pollen morphotypes are recognized and systematically treated. The relative abundances are determined for 15 samples, representative for the total of 51 prepared samples.

Three biozones are established, and based on the occurrence of selected morphotypes from ammonoid-zoned strata in England, Holland and DDR, the lowest zone is dated to latest Toarcian and the lower part of the middle zone to early Aalenian. The remainder of the Baga section is referred to Middle Jurassic by correlation to Swedish palynofloras.
\end{abstract}

Torsten Hoelstad, Institut for Historisk Geologi og Palceontologi, Oster Voldgade 10, 1350 København K, Denmark, November 13th, 1984.

\section{Introduction}

Jurassic, continental sediments of considerable thickness are exposed in the Bagågraven clay pit on the west coast of Bornholm, an island in the Baltic between Sweden and Poland (fig. 1).

The locality has for a long time been known for its deposits of coal. The coals, together with clay resources, a rich macroflora and the geology in general have been subject to scientific studies for more than a century.

Excavation for clay in the Bagå area commenced by the end of the 19th century. Descriptions of the clay mineralogy were given by Rördam (1890), Graff-Pedersen (1961) and Graff-Pedersen \& Bondam (1963).

The macroflora of the Bagå beds has been extensively studied by Bartholin $(1892,1894)$, Möller $(1902,1903)$ and Florin (1958). The main constituents of the flora are ferns, conifers and cycadophytes.

The geological setting with special emphasis on the coal seams was first described in 1837 by Forchhammer. He referred the sediments to the Bagå System and considered the northern and southern boundaries, which he named respectively the Levka- and the Sorthat Systems, as being faults. This view and the subdivision of the coal-bearing strata into three separate and faultbounded sequences are still maintained.

The general geology and stratigraphy of the Bagå beds were further treated by Jespersen (1865, 1866), Grönwall (1899), Malling (1920), Höhne (1933), Hansen (1939), Rosenkrantz (1939) and Gry (1951). Modern accounts were given by Gry (1969) and Gravesen, Rolle \& Surlyk (1982).

After a thorough discussion of previous views and based on the macrospore content Gry (1969) concluded that the age of the Baga beds is Middle Jurassic and that they probably are younger than the surrounding Levka- and Sorthat beds.

Gravesen et al. (1982) established a formal lithostratigraphic classification of the Jurassic deposits of Bornholm. In this classification the Bagå-, Levka-, and Sorthat sequences were included in the Bagå Formation. The formation has Bagågraven clay pit as type locality.

The Jurassic deposits of Bornholm, except for the extreme uppermost, are headed under the Bornholm Group (Gravesen et al. 1982); however, no profound revisions have been made concerning their internal subdivision. Thus, the tripartition in a Lower Limnic, Marine and Upper Limnic Series remain unchanged, but formal names were given. These are Rønne Formation, Hasle Formation and Bagå Formation. 


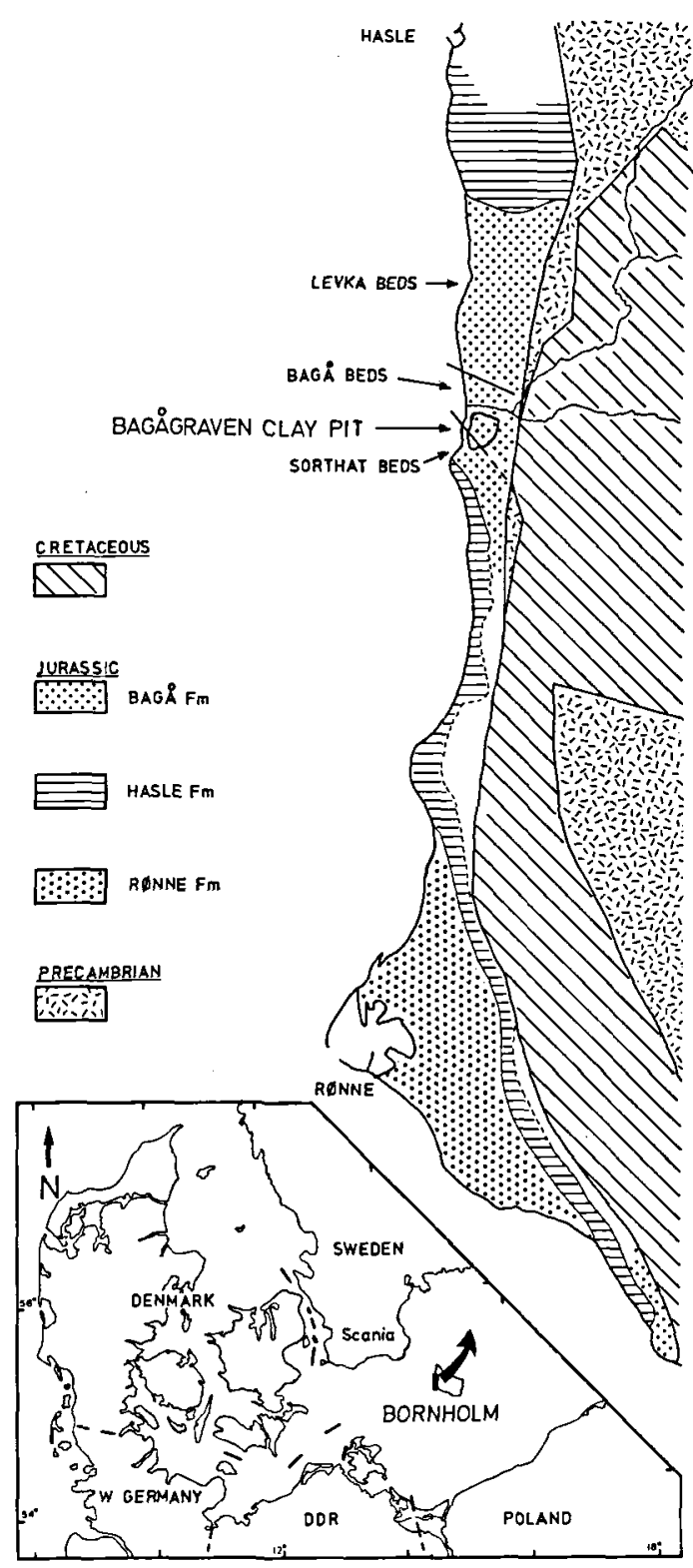

Fig. 1. Geological map of the SW-part of Bornholm (modified from Gry 1969).

Based on the macroflora and ammonites, the Rønne Formation and the Hasle Formation are well dated to Hettagian - Sinemurian and to Early Pliensbachian respectively (Harris 1937, Gry 1969, Malling \& Grönwall 1909). However, attempts to date the Bagå Formation by means of the macroflora (Florin 1958) and by the macrospore content (Gry 1969) fails to give a detailed stratigraphic account, although both methods indicate a Middle Jurassic age.

Applying palynology to the Bagå Formation has proven successful, as it has been possible to establish a biozonation and a basis for a chronostratigraphic placing. This was the ultimate aim of the present investigation, but the purpose was also a brief description of the majority of palynomorphs recovered and a systematic treatment af some ill-defined or problematic morphotaxa.

\section{Lithology and depositional environment}

The section forming the basis for the present investigation is located in the northern part of the Bagågraven clay pit (fig. 2). The thickness totals 103 metres and the dominating lithologies are sand, clay and coal (fig. 3). The sediments can be subdivided into three lithologic units.

The lower 20 metres (unit 1) are characterized by clay, but sand and coal occurs, especially in the middle part of the unit. One root horizon is present. Fining upwards sequences has not been recognized.

The overlying 51 metres of sediments (unit 2) are rather heterogeneous with root horizons, cyclic sedimentation and frequent deformation structures. The interval from 20 to 40 metres roughly equals the type section of the Baga Formation (Gravesen et al. 1982, p. 25).

The uppermost part of the section (unit 3 ) is dominated by coarse sediments. A mudflow horizon containing partly kaolinized granite boulders is present, so are two fining upwards sequences and one root horizon.

Judging from i.a. the rapidly changing lithology, the fining upwards sequences and the root horizons, it is most likely that the sediments were deposited in a fluvial or deltaic environment. This was noted by Gry (1969), who mentioned deltaic conditions in general, whereas Gravesen et al. (1982) more specifically pointed to a lower delta plain environment under marine influence. Finds of agglutinating foraminifera in the Sorthat beds (Gry 1969) are the basis for the conclusion of Gravesen et al. (1982) (Gravesen, pers. comm., 1984). However, no marine palynomorphs have been recovered in the Bagå section, 

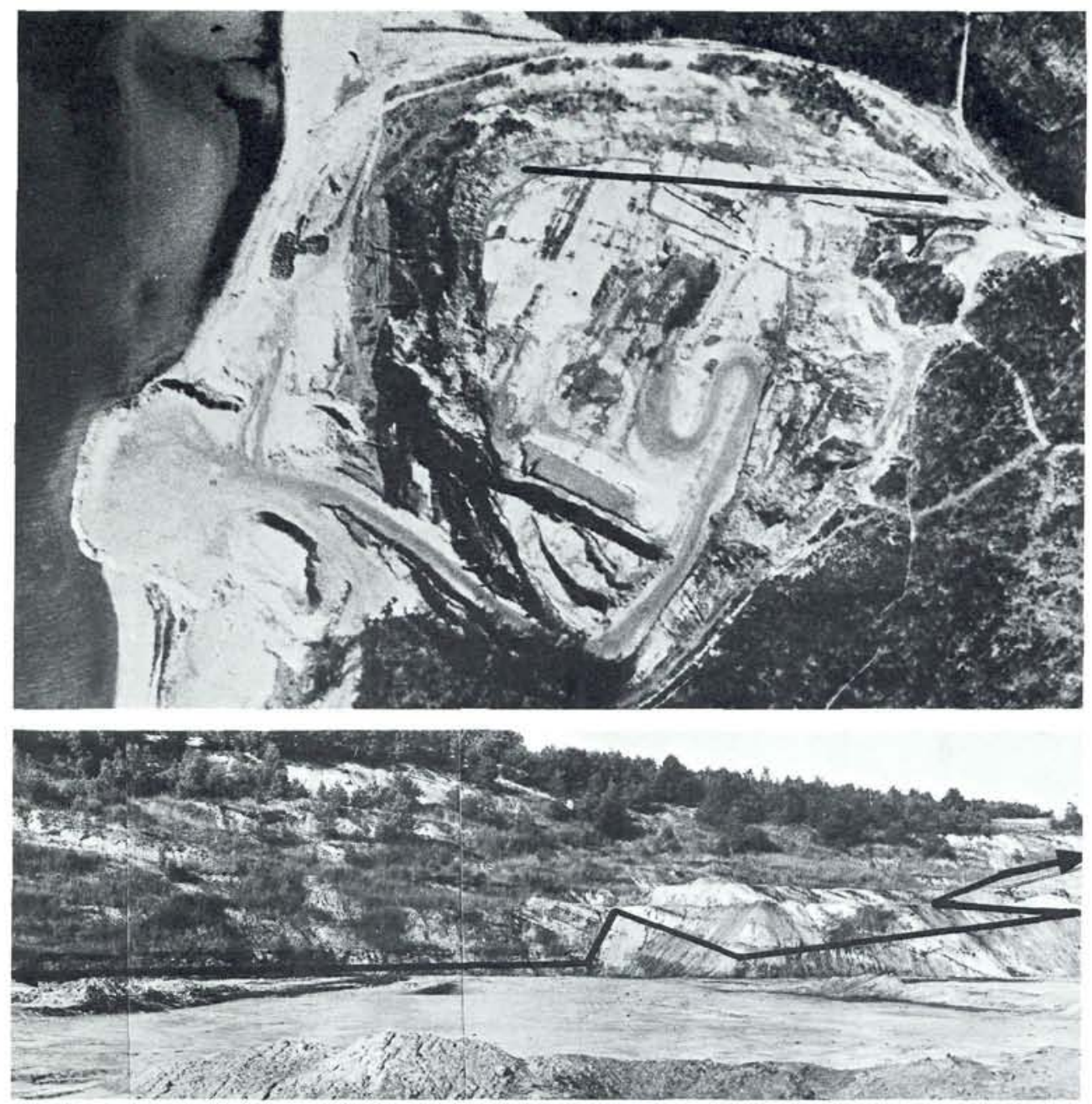

Fig. 2. Aerial view and panorama of Bagagraven with the investigated section indicated. Flyvefotografi: Geodatisk Institut. Rute 7402E, nr. 2957, 1974. Gengivet med instituttets tilladelse (A. 182/84). Copyright.

and a flood plain environment may be a better proposal for that particular section of the Bagå Formation. Unit 2 fits very well with that interpretation. The fine grained unit 1 and the coarse grained unit 3 can be seen respectively as flood plain basins of a coastal/delta plain environment and as a flood plain/alluvial fan environment. This also demonstrates the regressive nature of the Bagå Formation, because an advancing delta front increases the distance to sea of the depositional area behind it. In the actual case from a coastal area proximity to a source area proximity, thus the coastal/delta plain environment with strong clay accumulation is gradually replaced by a flood plain environment with extremely varied subenvironments. This environment is finally replaced by a flood plain/alluvial fan environment with mud flows.

\section{Sample preparation}

The samples have been passed through a standard procedure. After a mild surface washing the samples were crushed and $1,5 \mathrm{~g}$ were weighed out. This fraction of the material was chemically treated as follows: $10 \mathrm{~min}$. of cold $10 \% \mathrm{HCl}, 2 \times 2$ h. of $90^{\circ} \mathrm{C} 40 \% \mathrm{HF}$ and $20 \mathrm{~min}$. of $90{ }^{\circ} \mathrm{C} 10 \%$ 


\section{LEGEND}

\section{I THOLOGY}

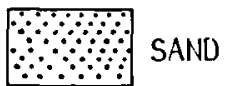

SANDSTONE

SILT

CLAY
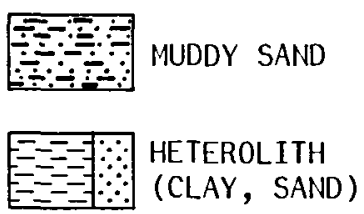

$E==-1$
$E==-1$

COAL

MUDDY COAL

\begin{tabular}{ll}
\hline $1,1,1$ & CARBONACEOUS \\
1,1 & DETRITUS
\end{tabular}

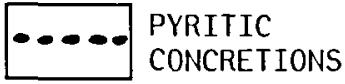

\begin{tabular}{|l|l} 
PARTLY \\
KAOLINIZED GRANITE
\end{tabular}

CONCEALED STRATA
SED IMENTARY

STRUCTURES

Sand

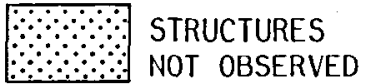

$=$ FAINT LAMINATION

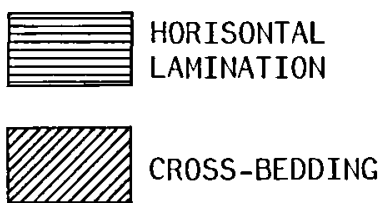

Heteroliths

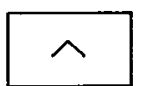

FLASER

LAMINATION

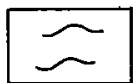

WAVY

LAMINATION

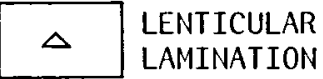

Silt and clay

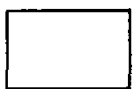

STRUCTURES NOT OBSERVED

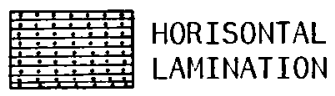

DEFORMATION

STRUCTURES

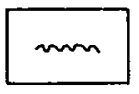

BIOGENIC STRUCTURES

$\lambda \lambda \lambda \lambda$ ROOTLETS

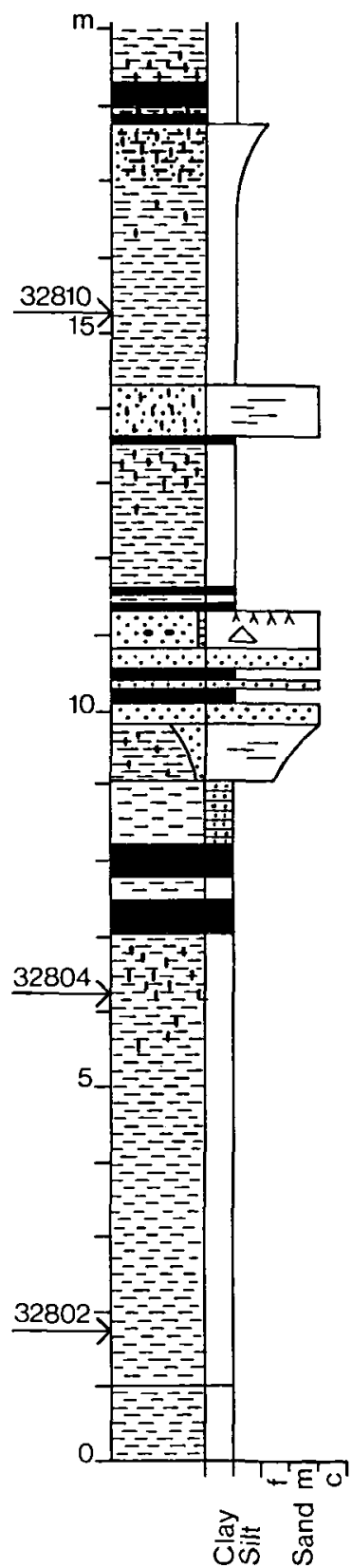

Fig. 3. The investigated section of the Bagå Formation, - lithology, texture and sedimentary structures. Measured 1979-80.

$\mathrm{HCl}$. The samples were then washed in $\mathrm{H}_{2} \mathrm{O}$ and sieved on a $10 \mu \mathrm{m}$ filter and the result checked. One or two steps in the procedure were repeated when necessary.

The organic residues were evaluated, attention being focused on the palynomorph content, as the purpose was exclusively biostratigraphy/systematics. In this context the optimal conditions for microscopical observations are clean preparations with transparent light brown palynomorphs. 


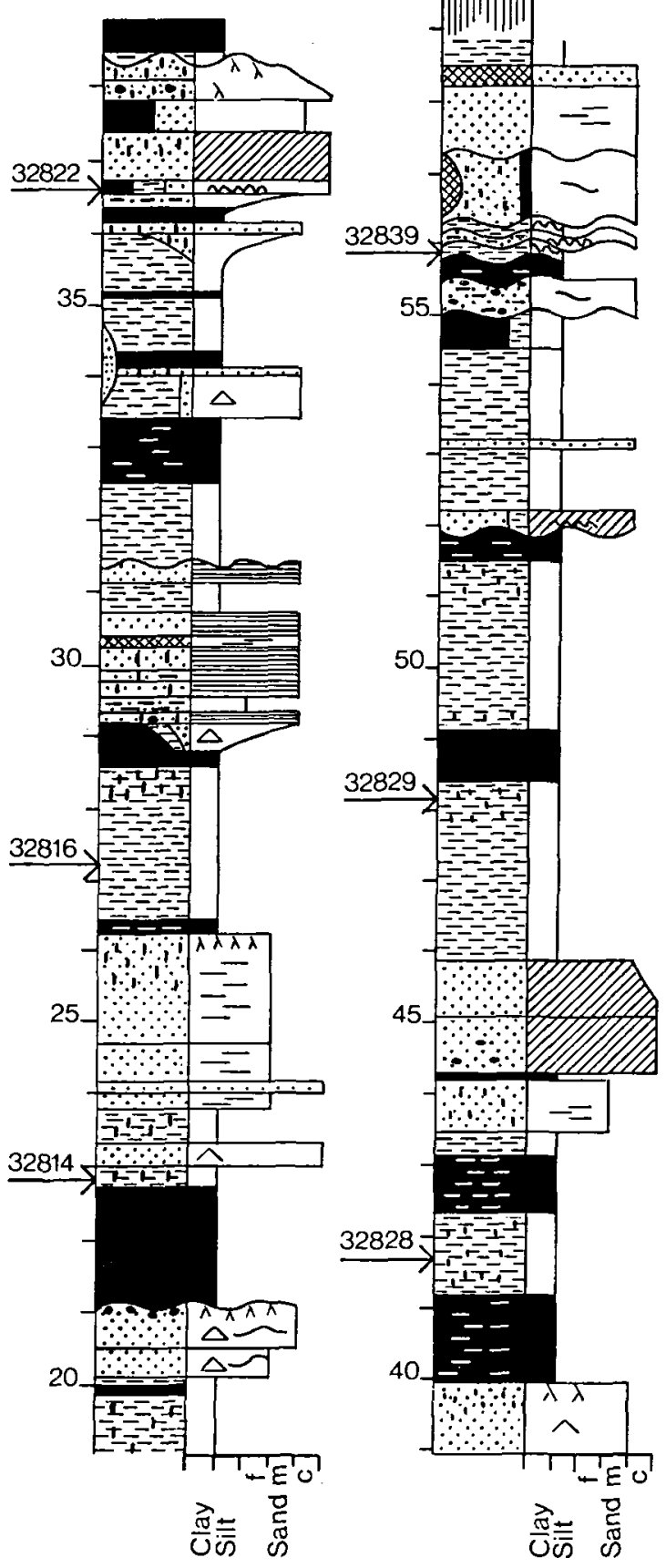

In order to achieve this, the samples were exposed to ultrasound, peptisator and thoroughly washed with $\mathrm{H}_{2} \mathrm{O}$ on a $10 \mu \mathrm{m}$ filter. The palynomorphs, if too dark, were bleached with $5 \%$ $\mathrm{KOH}$.
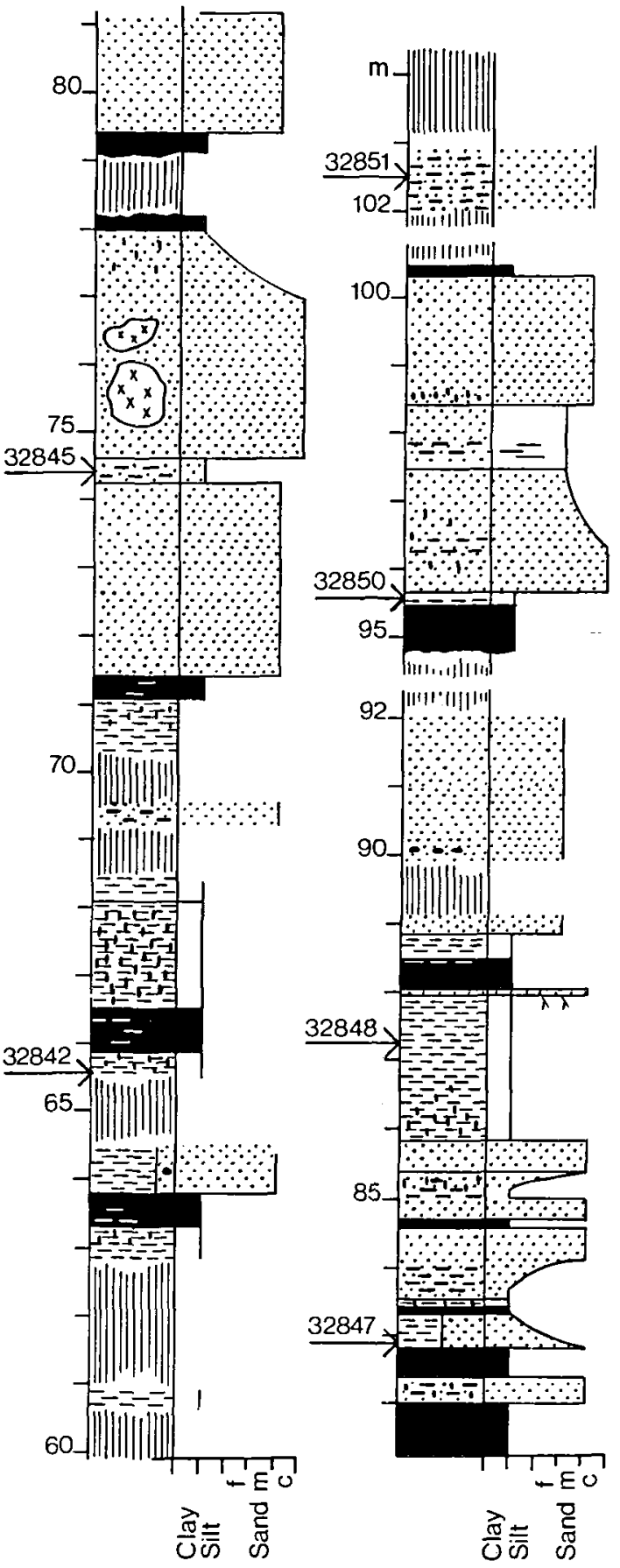

The organic residues were mounted and stored in glycerine. 51 samples were prepared.

All the samples have been microscopically scanned and 15 of the richest and most diverse 


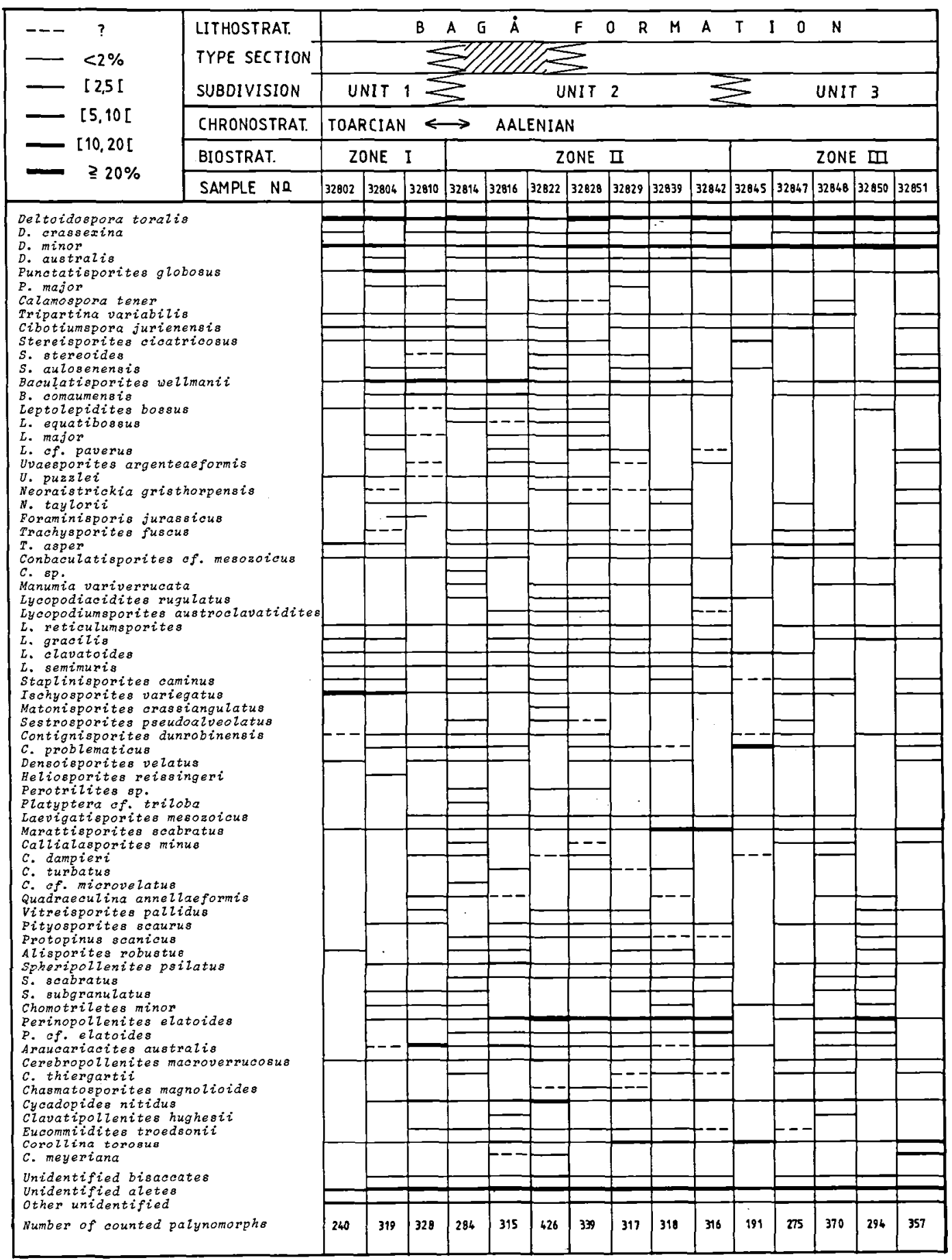

Fig. 4. Graphic representation showing the distribution and the relative abundances of the species recovered from the investigated section. 
from different levels through out the section were counted, fig. 4.

The samples are registered and deposited at the Department of Geology, University of Aarhus.

\section{Stratigraphical results}

The statigraphic distribution and relative abundance of the species recovered from the Baga section is shown in fig. 4.

All samples are characterized by a strong representation of stratigraphic long ranging species and a high relative abundance of Deltoidospora spp. and Aletes.

The distribution, concurrence and relative abundance of selected species, the overall richness (diversity) and number of Sporites species relative to the number of Pollenites species (the $\mathrm{S} / \mathrm{P}$ - coefficient) makes it possible to establish a biozonation with 3 zones (informal Oppel zonation, Hedberg 1972).

Zone I is characterized by relatively few (46) species. The $\mathrm{S} / \mathrm{P}$ - coefficient is 2.3. Foraminisporis jurassicus and Heliosporites reissingeri are restricted to Zone I and Ischyosporites variegatus and Araucariacites australis have high relative abundances in the lower and upper part of the zone respectively. The boundary between Zone I and Zone II is characterized by a high relative abundance of Baculatisporites wellmanii.

Zone II is marked by the incoming of 24 new species, of which almost half are referable to the Pollenites group and the S/P - coefficient thus decreases to 1.8. Important new species are Leptolepidites equatibossus, Neoraistrickia gristhorpensis, Manumia variverrucata, Matonisporites crassiangulatus, Sestrosporites pseudoalveolatus, Callialasporites minus and C. turbatus. Species restricted to Zone II are Leptolepidites equatibossus, Lycopodiumsporites austroclavatidites, Matonisporites crassiangulatus, Callialasporites turbatus and Chasmatosporites magnolioides.

Perinopollenites elatoides shows high relative abundances and so does Marattisporites scabratus in the upper part of the zone. The concurrent occurrence of all recognized species of genus Leptolepidites and genus Lycopodiumsporites characterizes the lower part of the zone.

Zone III starts with concurrent high relative abundances of Corollina torosus and Contignisporites problematicus and ends with concurrent high relative abundances of $C$. torosus and $C$. meyeriana. Otherwise, the characteristics of Zone III are sparse. 15 species present in Zone II are absent in Zone III and the S/P - coefficient decreases to 1.6. Especially the lack of Lycopodiumsporites semimuris and Callialasporites turbatus and the near absence of Eucommiidites troedssonii (only a single doubtful specimen) distinguish Zone III from Zone II. No new species occur.

The general trends in composition of the palynoflora are a steadily decreasing relative proportion of spores from base to top of the section and a pronounced maximum in richness of species in the middle part (Zone II).

It may be noted that the biozonation is roughly equivalent to the lithostratigraphic subdivision. Thus, it is possible that the changing palynoflora is a reflection of a changing depositional environment. However, the marked changes in the palynoflora at the boundary Zone I/Zone II do not correspond to a major shift in the depositional environment, as the lithologic transition from Unit 1 to Unit 2 is continuous.

Palynofloras with a change in composition similar to that between Zone I and Zone II have been observed in the Jurassic of Yorkshire, England (Couper 1958), DDR (Schulz 1967), eastern Holland (Herngreen \& de Boer 1974) and northern Denmark (Bertelsen 1974). Based on the data from these areas, the stratigraphic distribution of some important palynomorphs have been compiled, fig. 5. The occurrence of the same species from the Baga section (fig. 5) shows a distribution similar to the one seen at the boundary Toarcian/Aalenian (one discrepancy is the too late occurrence of Manumia variverrucata). It is thus presumed that the boundary Zone I/Zone II is equivalent to the boundary between Toarcian and Aalenian. The age determination of the lower part of the Baga section is highly facilitated by possibilities of correlation to ammonoid dated sections in England, DDR and Holland. Those possibilities are not present concerning the higher levels of the Bagå section.

Palynologic investigations in Scania, southern Sweden (Tralau 1968, Guy 1971, Guy-Ohlson 1978) have yielded palynomorph assemblages interpreted as Middle Jurassic, which are almost 


\begin{tabular}{|c|c|c|c|c|}
\hline \multirow{2}{*}{$\begin{array}{l}\text { LEGEND } \\
- \text { - ENGLAND (Couper 1958) } \\
\ldots \ldots \text { DDR (Schulz 1967) } \\
\text {--- HOLLAND (Herngren } 2 \text { de Boer 1976) } \\
\ldots \ldots \text {.... DENMARK (Bertelsen 1978) }\end{array}$} & \multicolumn{2}{|c|}{$\begin{array}{l}\text { DISTRIBUTION } \\
\text { IN NORTHWEST } \\
\text { EUROPE }\end{array}$} & \multicolumn{2}{|c|}{$\begin{array}{l}\text { DISTRIBUTION } \\
\text { IN THE BAGA } \\
\text { SECTION }\end{array}$} \\
\hline & $\begin{array}{l}\text { TOARCIAN } \\
1 / 1\end{array}$ & $\begin{array}{c}\text { AALENIAN } \\
1\end{array}$ & $\begin{array}{c}\text { ZONE } \\
I\end{array}$ & $\begin{array}{c}\text { ZONE } \\
\text { II }\end{array}$ \\
\hline \multicolumn{5}{|l|}{ Leptolepidites bossus } \\
\hline \multicolumn{5}{|l|}{ Leptolepidites equatibossus } \\
\hline \multicolumn{5}{|l|}{ Leptolepidites major } \\
\hline \multicolumn{5}{|l|}{ Neoraistrickia gristhorpensis } \\
\hline \multicolumn{5}{|l|}{ Foraminisporis jurassicus } \\
\hline \multicolumn{5}{|l|}{ Manumia variverrucatus } \\
\hline \multicolumn{5}{|l|}{ Staplinisporites cominus } \\
\hline \multicolumn{5}{|l|}{ Ischyosporites variegatus } \\
\hline Matonisporites crassiangulatus & & & & - \\
\hline Sestrosporites pseudoalveolatus & & $\therefore=$ & & \\
\hline Heliosporites reissingeri & $\because$ & & - & \\
\hline Callialasporites dampieri & & & & \\
\hline Calzialasporites turbatus & & $\therefore:::$ & & \\
\hline
\end{tabular}

Fig. 5. Distribution in North West Europe of selected species with special emphasis on the boundary Toarcian/Aalenian compared with distribution of the same species from the Bagå section.

similar to those recovered from Zone II and Zone III.

Thus, the age of Zone I can be referred to latest Toarcian, that of the lowermost Zone II to Aalenian, and the remainder of the section to Middle Jurassic by correlation to Scania. Whether the Bagå section includes all Middle Jurassic stages or only the lowermost cannot, however, be determined yet.

\section{Conclusion}

The present investigation of the Bagå beds has revealed a diverse assemblage of well preserved spores and pollen, permitting the establishment of three biozones (Zone I-III).
The age of the boundary between Zone I and Zone II is, by correlation to palynologically investigated and ammonoid zoned strata in NorthWest Europe, determined to the boundary Toarcian/Aalenian. The palynoflora of the upper two zones (Zone II and III) equivalates palynofloras of Scania, interpreted as Middle Jurassic.

Thus, the investigated section of the Baga Formation (103 meters) can with certainty be referred to the uppermost Lower and lower Middle Jurassic. The extent of the section into the Middle Jurassic is as yet unknown.

No marine palynomorphs have been recovered. This, together with the sedimentology of the Bagå section, indicates that the bulk of sediments was deposited in a flood plan environment. 


\section{Systematics}

Anteturma SPORITES H. Potonié

Subturma AZONOTRILETES Luber emend. Dettmann 1963

Infraturma LAEVIGATI Bennie \& Kidston emend. Potonié 1956

Genus Deltoidospora Miner 1935 emend. DanzéCorsin \& Laveine 1963

1953: Cyathidites Couper

1953: Concavisporites Pflug

1954: Leiotriletes Naumova emend. Potonié \& Kremp

1955: Biretisporites Delcourt \& Sprumont

Leschik 1955: Laevigatisporites (Bennie \& Kidston) Ibrahim

1958: Dictyophyllites Couper

1959: Intrapunctisporis Krutzsch

Considerable confusion prevails concerning the classification of laevigate triangular spores. The basic difficulties are obviously that such spores possess few, but highly variable, characters. This has led to the establishment of several almost inseparable taxa. Many of the laevigate triangular spores, abundant in the Bagå samples, can be ascribed to these taxa, but just as many are intermediate forms and remain unclassified. It is therefore feasible to use broadly defined taxa. The appropriate genus is Deltoidospora Miner emend. Danzé-Corsin \& Laveine 1963, as it agrees with the principle of priority, and as it includes trilete spores with triangular to subtriangular amb, long sutures often bordered by folds and laevigate to finely infrastructured exine. This excludes from Deltoidospora only laevigate triangular spores with particular and persistent characters e.g. Tripartina and Cibotiumspora.

Deltoidospora toralis (Leschik 1955) Lund 1977 Plate 1, figs. 1-2.

1958: Concavisporites toralis (Leschik 1955) Nilsson

D. toralis is identified by having folds along the sutures and/or a thickened contact area. These two characters are correlative because a differentiated exine must be rather susceptible to folding during compression and because folding tends to obscure thickenings of the exine. $D$. toralis thus includes all forms with a thickened contact area, but only part of those without.

Deltoidospora crassexina (Nilsson 1958) Lund 1977

Plate 1, fig. 5.

Similar to $D$. toralis except for a thicker exine, $1.5-3 \mu \mathrm{m}$.

Deltoidospora minor (Couper 1953) Pocock 1970 Plate 1, figs 3-4.

$D$. minor includes small to medium sized, undeformed triangular spores with a laevigate to weakly infrastructured exine of uniform thickness, 1-2 $\mu \mathrm{m}$.

\section{Deltoidospora australis (Couper 1953) Pocock 1970}

Plate 1, fig. 6.

Equatorial diameter larger than $55 \mu \mathrm{m}$, otherwise as D. minor.

Genus Punctatisporites Ibrahim emend. Potonié \& Kremp 1954

Punctatisporites globosus (Leschik 1955) Lund 1977

Plate 1, fig. 8.

Apart from a slightly thinner exine and a circular amb $P$. globosus and $P$. major parallels $D$. minor and $D$. australis. Size separation at $52 \mu \mathrm{m}$.

Punctatisporites major (Couper 1958) Kedves \& Simonsics 1964

Genus Calamospora Schopf, Wilson \& Bentall

Calamospora tener Leschik 1955 emend. Mädler 1964

Plate 1, fig. 7.

Genus Tripartina Malyavkina 1949 emend. Potonié 1960

Lectotype Tripartina variabilis Malyavkina 1949 designated by Potonié 1960 .

Tripartina Malyavkina 1949 was validly published according to ICBN (Traverse \& Ames, vol. 40 , p. 66), but no holotype was designated. Later Malyavkina (1953, 1964) stated additional diagnoses and designated $T$. ornata as type (Malyavkina 1964). However, a lectotype was already 

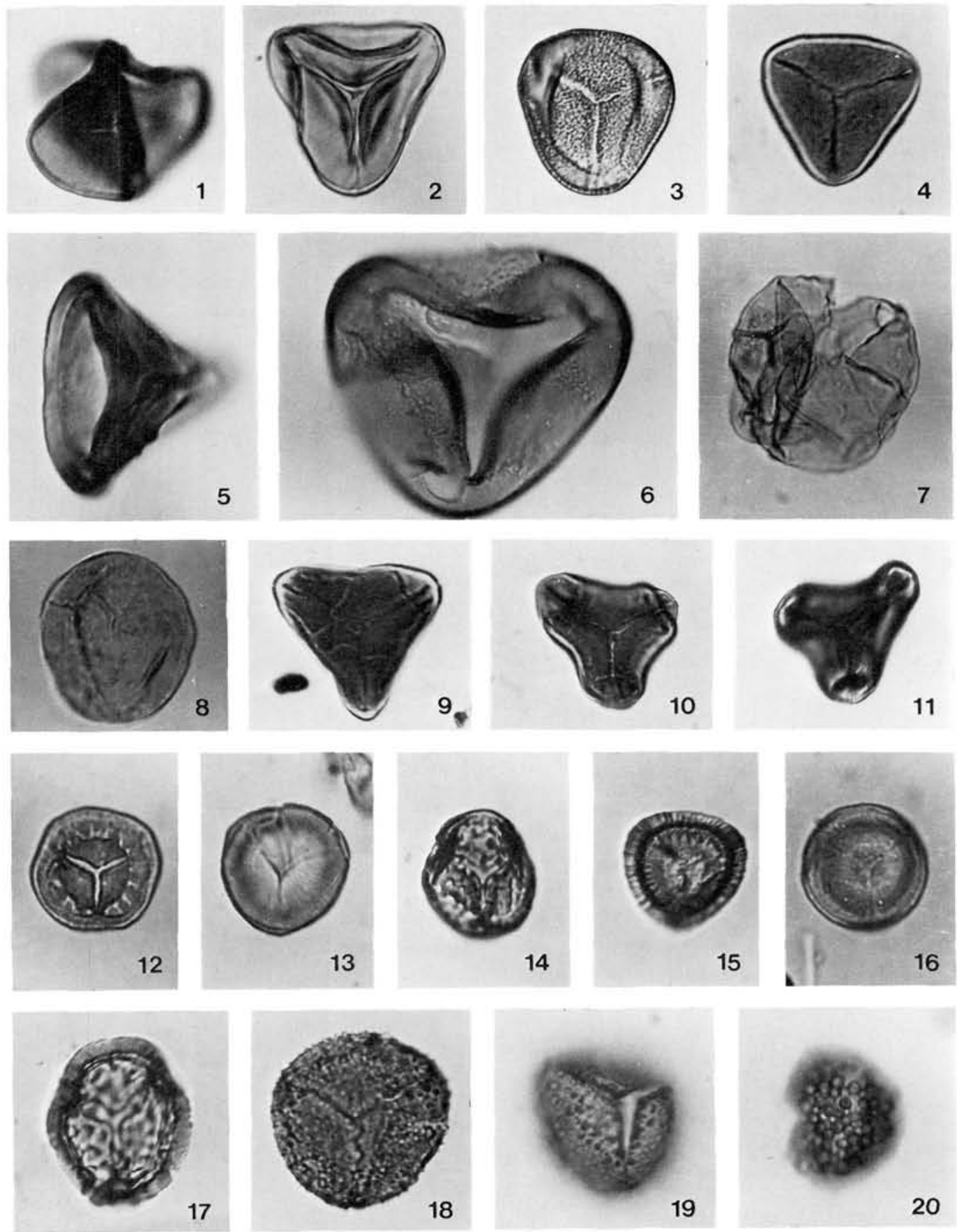

Plate 1.

Figs. 1-2; Deltoidospora toralis, figs. 3-4; Deltoidospora minor, fig. 5 ; Deltoidospora crassexina, fig. 6; Deltoidospora australis, fig. 7 ; Calamospora tener, fig. 8; Punctatisporites globosus, fig. 9; Tripartina variabilis, figs. 10-11; Cibotiumspora jurienensis, fig. 12; Stereisporites cicatricosus, fig. 13, Stereisporites stereoides, fig. 14; Stereisporites aulosenensis, figs. 14-16; Stereisporites spp., fig. 17; Baculatisporites wellmanii, fig. 19; Baculatisporites comaumensis, fig. 20; Leptolepidites bossus. All figures approx. $750 \mathrm{X}$. 
designated by Potonie (1960) and so the type $T$. ornata is superflous. In the same work Potonié altered the generic diagnosis on basis of the species description for T. cretacea (Malyavkina 1949, p. 48), thus the original diagnosis (Malyavkina 1949 , p. 31) seems to be overlooked. In spite of that, Potonié clarified the diagnosis as emphasis was placed on the radial sculpture.

Tripartina variabilis Malyavkina 1949

Plate 1, fig. 9.

Guy 1971: Undulatisporites concavus Kedves Filatoff 1975: Cf. Obtusisporis canadensis Pocock

Malyavkina subdivided the species $T$. variabilis into several subspecies. $T$. variabilis here includes all varieties except for the smooth $T$. variabilis var. glabra Malyavkina 1949.

T. variabilis may have a local stratigraphic potential in the Lower Jurassic as it is present in the Middle Jurassic of Scania (Guy 1971) and the late Lower to Middle Jurassic of Bornholm, but absent in the Rhaetic to Lower Liassic of Scania (Guy-Ohlson 1981) and the south-eastern North Sea Basin (Lund 1977).

Genus Cibotiumspora Chang 1965 emend. Filatoff 1975

Cibotiumspora jurienensis (Balme 1957) Filatoff 1975

Plate 1, figs. 10-11

The species was by several authors placed in the genus Concavisporites Pflug 1953 (i.a. Balme 1957, Kedves and Simoncsics 1964, Guy 1971 and Schuurman 1977). However, C. jurienensis can be distinguished from other laevigate triangular spores by the characteristic distal folds.

Genus Stereisporites Pflug 1953 sensu lato Krutzsch 1963.

The general features of genus Stereisporites are a relatively thick not folded exine, small dimension, laevigate proximal face and an extremely varied equatorial and distal sculpture.

Stereisporites cicatricosus Rogalska emend. Danzé-Corsin \& Laveine 1963

Plate 1, fig. 12.

$S$. cicatricosus is characterized by a distal polar thickening encircled by radial grooves.
Stereisporites stereoides (Potonié \& Vernitz) Thomsen \& Pflug 1953

Plate 1, fig. 13.

Exclusively laevigate, but often exhibiting a weak distal exine differentiation and fine radial tendencies.

Stereisporites aulosenensis (Schulz 1967) Schulz 1966

Plate 1, fig. 14

Distal sculpture rugulate/reticulate.

Stereisporites spp.

Plate 1, figs 15-17.

The genus Stereisporites includes more than 50 species (Döring, Krutzsch, Schulz \& Timmermann 1966, Schulz 1970). However, none of the previously described species conform exactly to those here figured.

Infraturma APICULATI Bennie \& Kidston emend. Potonié 1956

Genus Baculatisporites Thomson \& Pflug 1953 emend. Krutzsch 1967

1953: Osmundacidites Couper

Baculatisporites wellmanii (Couper 1953) Krutzsch 1959

Plate 1, fig. 18

Baculatisporites comaumensis (Cookson 1953) Potonié 1956

Plate 1, fig. 19.

$B$. comaumensis is distinguished from $B$. wellmanii by a less dense sculpture of larger elements.

Genus Leptolepidites Couper 1958 emend. Schulz 1967

Leptolepidites bossus (Couper 1958) Schulz 1967 Plate 1, fig. 20.

Characterized by equally distributed spherical verrucae and pila.

Diameter of pila about $2 \mu \mathrm{m}$.

Leptolepidites equatibossus (Couper 1958) Tralau 1968

Plate 2, fig. 1.

Exine verrucate except for the pilate sculptured equatorial region. 

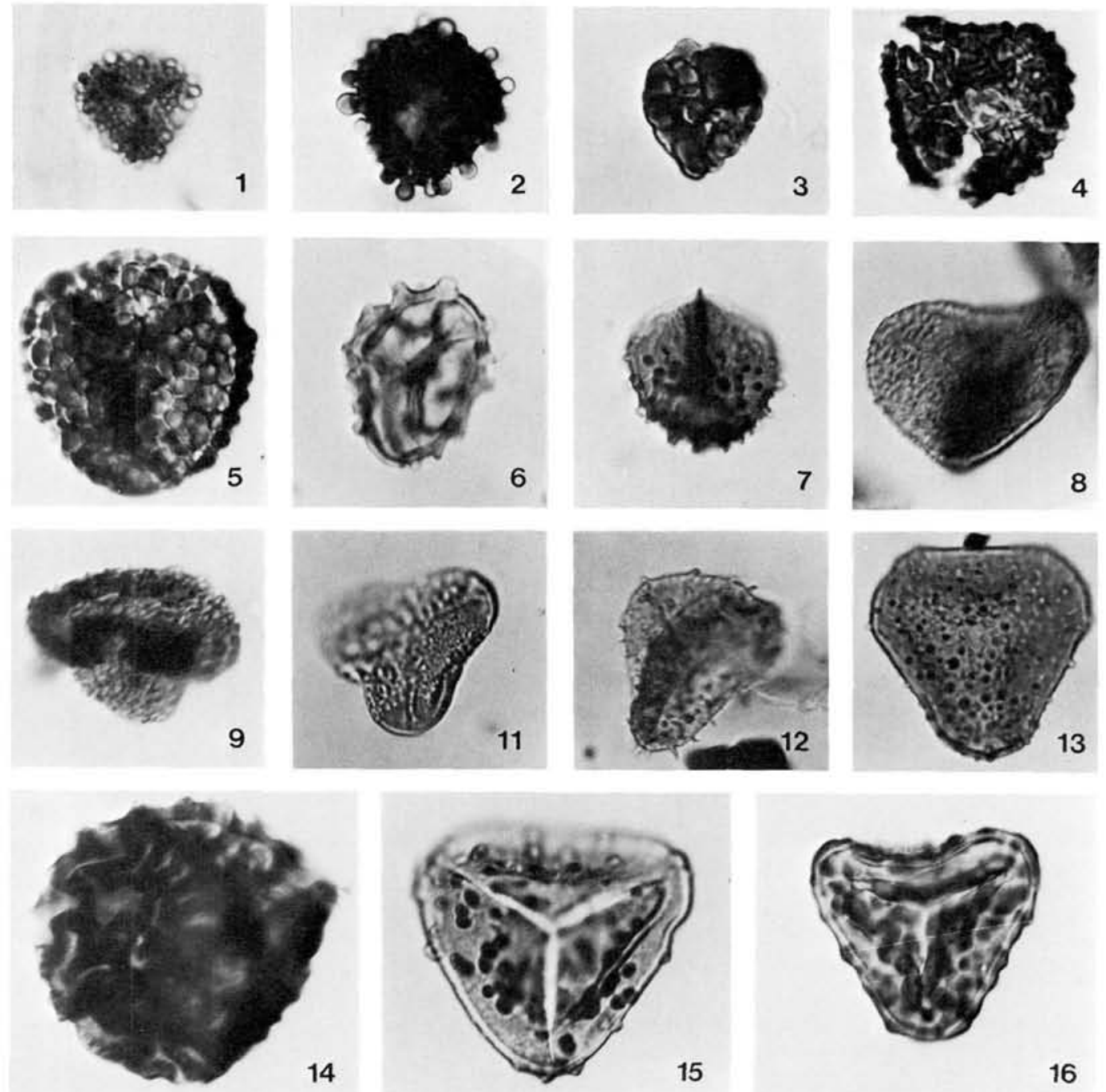

15

16
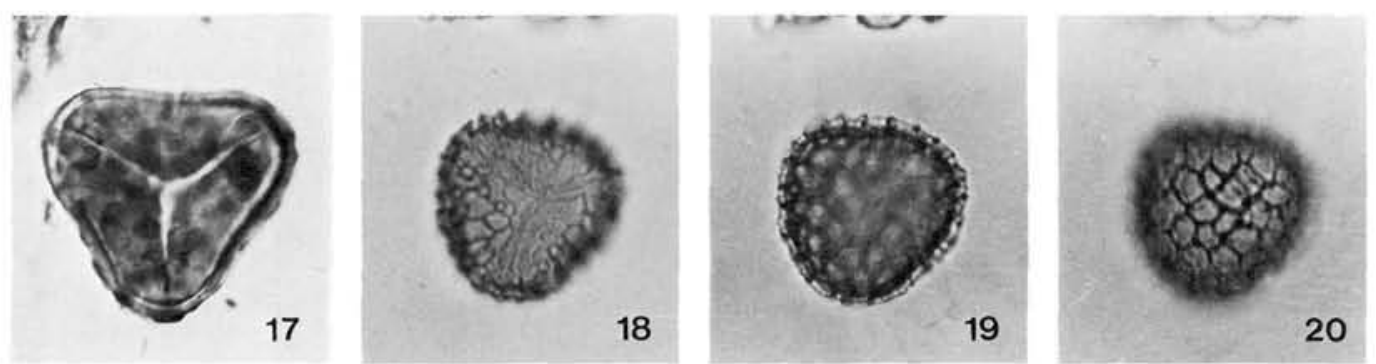

Plate 2.

Fig. 1; Leptolepidites equatibossus, fig. 2; Leptolepidites major, fig. 3; Leptolepidites cf. paverus, fig. 4; Uvaesporites puzzlei, fig. 5 ; Uvaesporites argenteaeformis, fig. 6; Neoraistrickia gristhorpensis, fig, 7; Neoraistrickia taylorii, fig. 8; Trachysporites fuscus, fig. 9; Trachysporites asper, fig. 11; Strongly corroded Deltoidospora sp., fig. 12; Cf. Conbaculatisporites mesozoicus, fig. 13; Conbaculatisporites sp., figs. 15-17; Manumia variverrucata, fig. 14; Lycopodiacidites rugulatus, figs. 18-20; Lycopodiumsporites reticulumsporites All figures approx. $750 \mathrm{X}$. 
Leptolepidites major Couper 1958

Plate 2, fig. 2.

Similar to $L$. bossus apart from larger spherical verrucae and pila.

Leptolepidites cf. paverus Levet-Carette 1964

Plate 2, fig. 3.

Differs from $L$. paverus by having fewer verrucae and a smaller equatorial diameter.

\section{Genus Uvaesporites Döring 1965}

Uvaesporites argenteaeformis (Bolkhovitina)

Schulz 1967

Plate 2, fig. 5.

Uvaesporites puzzlei Guy 1971

Plate 2, fig. 4.

$U$. puzzlei is characterized by a distal sculpture of elongate sometimes coalescent verrucae.

The type has not been recovered in the Rhaetic to Lower Liassic of Scania (Guy-Ohlson 1981) but is present in the Scanian Middle Jurassic (Guy 1971) and may thus be indicative of a Late Liassic to Middle Jurassic age.

\section{Genus Neoraistrickia Potonié 1956}

Neoraistrickia gristhorpensis (Couper 1958) Tralau 1968

Plate 2, fig. 6.

Neoraistrickia taylorii Playford \& Dettmann 1965 Plate 2, fig. 7.

Genus Foraminisporis Krutzsch 1959

Foraminisporis jurassicus Schulz 1967

Only a single specimen has been recovered (sample no. 32809)

\section{Genus Trachysporites Nilsson 1958}

The genus comprises spores with various types of microsculpture.

Trachysporites fuscus Nilsson 1958

Plate 2, fig. 8.

\section{Trachysporites asper Nilsson 1958}

Plate 2, fig. 9.

This species is similar to $T$. fuscus but has a considerably thinner exine.

The differentiation between strongly corroded Deltoidospora sp. (plate 2, fig. 11) and T. asper is doubtful, because of the resemblance in exine structure/sculpture.

\section{Genus Conbaculatisporites Klaus 1960}

Although not entirely in agreement with the generic diagnosis, the approach of Lund (1977), Schuurman (1977) and Pedersen \& Lund (1980) as to include in Conbaculatisporites forms with sculptural elements other than bacula is followed.

Cf. Conbaculatisporites mesozoicus Klaus 1960 Plate 2, fig. 12.

Spore trilete with triangular amb. Exine less than $1 \mu \mathrm{m}$ thick, sculptured with grana and 1-3 $\mu \mathrm{m}$ high bacula and spinae. Equatorial diameter $30-40 \mu \mathrm{m}$.

Conbaculatisporites sp.

Plate 2, fig. 13.

Spore trilete with triangular amb, straight sides and rounded apices. Exine covered with bacula, about $1 \mu \mathrm{m}$ in diameter and 1-2 $\mu \mathrm{m}$ high. Sculpture slightly denser at the apices.

\section{Genus Manumia Pocock 1970}

Manumia is characterized by having long, simple or labrate sutures, a triangular amb and an exine with irregular spaced verrucae or spinae. Radial crassitude can be present.

Manumia variverrucata Couper 1958 comb. nov. et emend.

Plate 2, fig. 15-17.

1958: Concavisporites variverrucatus Couper 1967: Trilites minutus (Bolkhovitina) Schulz 1971: Cf. Converrucosisporites variverrucatus ((Couper) Norris) Guy

1974: Trilites sp. Herngreen \& de Boer

Spore trilete with triangular amb, straight, weakly concave or convex sides and rounded apices. Sutures simple or labrate, almost reaching the equator. Exine 1-2 $\mu \mathrm{m}$ thick with none or a weak tendency to valvae. Spore sculptured with irregularly distributed, sometimes coalescent verrucae, about $1 \mu \mathrm{m}$ high and $2-4 \mu \mathrm{m}$ broad. Equatorial diameter 30-50 $\mu \mathrm{m}$.

The present type is ascribed to genus Manumia because genera such as the too broadly defined Trilites Cookson ex Couper, the dense sculptured Converrucosisporites Potonié \& Kremp 1954, and 
the mainly laevigate Concavisporites Pflug 1953, seem less suitable.

Manumia variverrucata has its first occurrence in Lower Toarcian (Schulz 1967, Herngreen \& de Boer 1974).

\section{Infraturma MURORNATI Potonié \& Kremp 1954}

Genus Lycopodiacidites Couper 1953 emend. Potonié 1956

Lycopodiacidites rugulatus (Couper 1958) Schulz 1967

Plate 2, fig. 14

Spore trilete with subcircular amb. Exine except for contact area covered with 1-3 $\mu \mathrm{m}$ wide sometimes coalescent rugulae and longish verrucae.

Genus Lycopodiumsporites Thiergart ex. Delcourt \& Sprumont 1955

1963: Rititriletes Van der Hammen ex. Pierce emend. Döring, Krutzsch, Mai \& Schulz.

Trilete spores with a subtriangular to subcircular amb and a more or less perfect reticulate sculptured distal exine are ascribed to genus Lycopodiumsporites. Even though the validity of the genus is doubtful. (Döring et al. 1963, Dettman 1963, Tralau 1968), it is a widely used genus, and is here regarded as a sort of "nomina conservanda".

A selection of species with perfect reticulate distal and equatorial exines is listed in Tab. 1. It may be noted that all forms have an equatorial diameter in the interval $22-58 \mu \mathrm{m}$ and that they all have representatives in the interval $30-40 \mu \mathrm{m}$.

Based on diameter of luminae, height of muri and presence of contact area sculpture, four species can be selected.

Lycopodiumsporites austroclavatidites (Cookson 1953) Potonié 1956

Plate 3, fig. 1.

Identified by a distal and equatorial reticulum with large luminae and high muri.

Lycopodiumsporites reticulumsporites (Rouse 1959) Dettmann 1963

Plate 2, figs. 18-20.

Identified by a distal and equatorial reticulum with small luminae and low muri and a somewhat reduced and less tight reticulum on the proximal side.

\section{Lycopodiumsporites gracilis Nilsson 1958}

Plate 3, fig. 2.

Similar to L. austroclavatidites except for considerably smaller luminae and lower muri.

Lycopodiumsporites clavatoides Couper 1958 emend. Tralau 1968

Plate 3, fig. 3.

Identified by a reticulate sculpture with large luminae and low muri.
L. reticulumsporites (Rouse) Dettmann - Tralau 1968

L. clavatoides Couper enend. Tralau 1968

L. clavatoides Couper emend. Tralau - Guy 1971

L. reticulumsporites (Rouse) Dettmann - Guy 1971

L. vilhelmil Guy 1971

L. austroclavatidites (Cookson) Potonié - Dettmann 1963

L. reticulumsporites (Rouse) Dettmann 1963

R. austroclavatidites (Cookson) Döring et al. - van Erve 1977

R. clavatoides (Couper) Döring et al. - van Erve 1977

R. clavatoides (Couper) Döring et al. - Schulz 1967

L. gracilis Nilsson 1959

A. gracilis (Nilsson) Döring et al. - Schulz 1987

L. austroclavatidites Cookson - Burger 1966

L. clavatoides Couper 1958

L. austroclavatidites (Cookson) Focock 1962

sp. $1: \mathrm{L}$. austroclavatidites (Cookson) Potoní́ 1956

sp. 2: L. reticulumsporites (Rouse) Dettmann 1963

sp. 3: L. gracills Nilsson 1950

sp. 4; L. clavatoides Couper enend. Tralau 1968

\begin{tabular}{|c|c|c|c|c|c|}
\hline $\begin{array}{l}\text { Equatorial } \\
\text { diameter in } \mu \mathrm{m}\end{array}$ & $\begin{array}{l}\text { Diameter of } \\
\text { luminae in } \mu \mathrm{m}\end{array}$ & $\begin{array}{l}\text { Height of } \\
\text { muri in } \mu m\end{array}$ & & $\begin{array}{l}\text { Contact area } \\
\text { sculpture }\end{array}$ & Species \\
\hline $22-35$ & $1-5$ & 1 & & + & sp. 2 \\
\hline $28-35$ & $6-14$ & $1-1.5$ & & - & sp. 4 \\
\hline $28-35$ & $8-13$ & $0.8-1.6$ & & - & sp. 4 \\
\hline $32-42$ & $1-5$ & 1 & ! & + & sp. 2 \\
\hline $37-54$ & $8-14$ & $3-7$ & $\mid$ & - & sp. 1 \\
\hline $34-58$ & $7-12$ & $2-3$ & 1 & - & sp. $4 ?$ \\
\hline $25-29$ & $2-6$ & 1 & i & + & sp. 2 \\
\hline $28-35$ & $3-4$ & 2 & 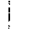 & - & sp. 3 \\
\hline $32-37$ & $6-9$ & 5 & 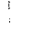 & - & sp. 1 \\
\hline $30-43$ & $6-14$ & $3-4$ & & - & $s p .1$ \\
\hline $28-33$ & $4-5$ & $2-3$ & & - & sp. 3 \\
\hline $32-36$ & $2-5$ & $1-2$ & & - & sp. 3 \\
\hline $40-50$ & $5-10$ & $3-5$ & & - & $\mathrm{sp} \cdot 1$ \\
\hline $25-50$ & $8-15$ & 4 & & - & sp. 1 \\
\hline $30-45$ & $6-10$ & $1-4$ & & - & sp. 1 \\
\hline $30-35$ & $5-12$ & $3-4$ & 1 & - & \\
\hline $25-30$ & $2-4$ & 1 & & + & \\
\hline 32 & $3-5$ & $2-3$ & & - & \\
\hline $25-35$ & $6-12$ & $1-2$ & & - & \\
\hline
\end{tabular}

Table 1

Comparison of species referred to genus Lycopodiumsporites/Retitriletes. Four morpho-types can be selected (right hand column), and according to the principle of priority, their epithets are as indicated. 

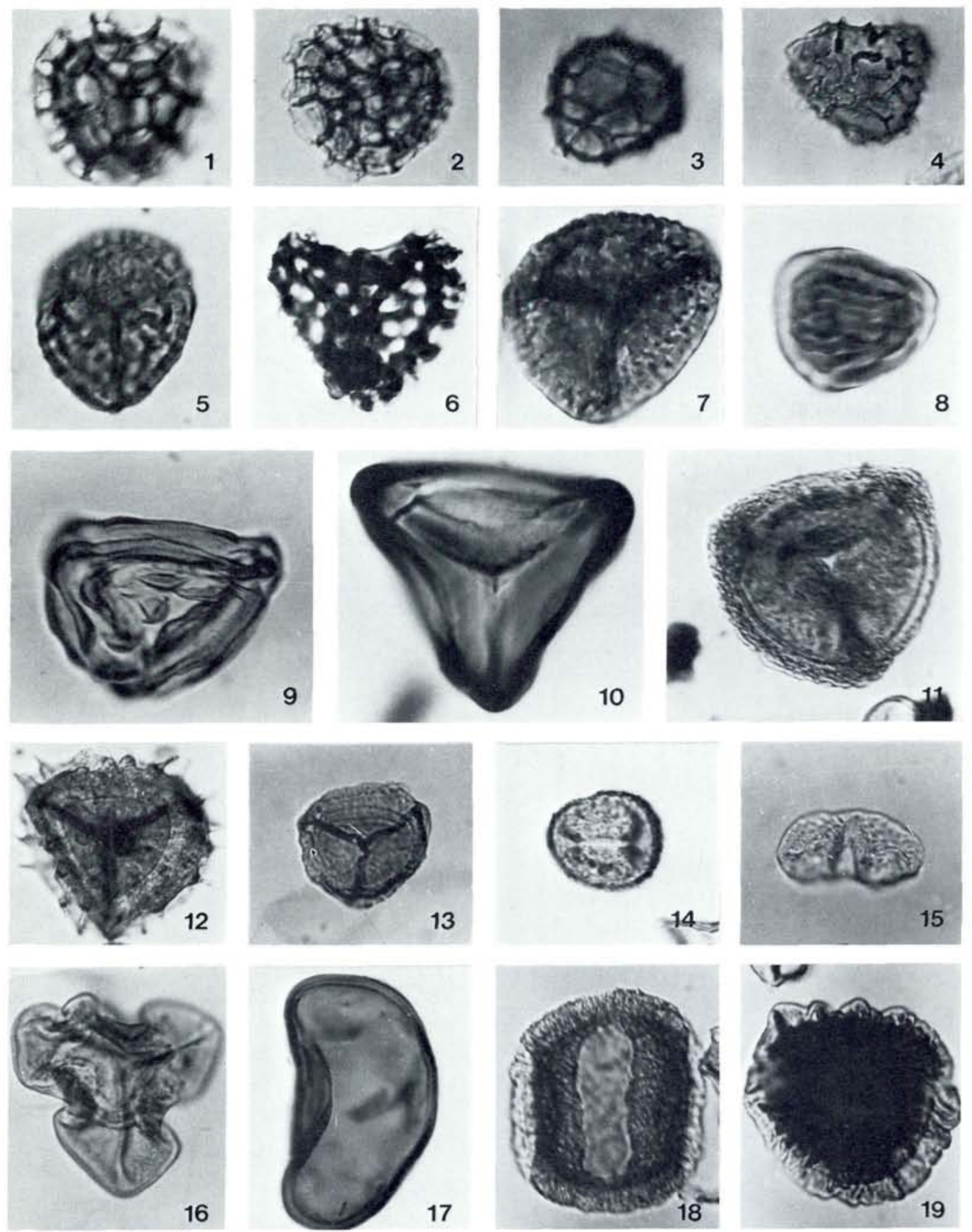

Plate 3.

Fig. 1; Lycopodiumsporites austroclavatidites, fig. 2 ; Lycopodiumsporites gracilis, fig. $3 ;$ Lycopodiumsporites clavatoides, fig. 4 ; Lyco. podiumsporites semimuris, fig. 5; Staplinisporites caminus, fig. 6; Ischyosporites variegatus, fig. 7; Sestrosporites pseudoalveolatus, fig. 8; Contignisporites problematicus, fig. 9; Contignisporites dunrobinensis, fig. 10; Matonisporites crassiangulatus, fig. 11; Densoisporites velatus, fig. 12; Heliosporites reissingeri, fig. 13; Perotrilites sp., fig. 14; Marattisporites scabratus, fig. 15; Vitreisporites pallidus, fig. 16; Cf. Platyptera triloba, fig. 17; Laevigatosporites mesozoicus, fig. 18; Quadraeculina anellaeformis fig. 19: Callialasporites minus. All figures approx. $750 \mathrm{X}$. 
Lycopodiumsporites semimuris Danzé-Corsin \& Laveine 1963

Plate 3, fig. 4.

$L$. semimuris is distinguished from all other species of genus Lycopodiumsporites by the imperfect reticulate sculpture.

\section{Genus Staplinisporites Pocock 1962}

Staplinisporites caminus (Balme 1957) Pocock 1962

Plate 3, fig. 5.

Characterized by a distal sculpture comprising a concentric irregular band of thickened exine surrounded by more or less radial muri and a circular granulate polar exine thickening.

Subturma ZONOTRILETES Waltz Infraturma AURICULATI Schopf emend. Dettmann 1963

Genus Ischyosporites Balme 1957

Ischyosporites variegatus (Couper 1958) Schulz 1967

Plate 3, fig. 6.

I. variegatus is readily recognized by a thick exine and a distinct foveolate to foveo-reticulate distal sculpture.

Genus Matonisporites Couper 1958 emend. Dettmann 1963

Matonisporites crassiangulatus (Balme 1957)

Dettmann 1963

Plate 3, fig. 10.

Infraturma TRICRASSATI Dettmann 1963

Genus Sestrosporites Dettmann 1963

Sestrosporites pseudoalveolatus (Couper 1958)

Dettmann 1963

Plate 3, fig. 7.

Exhibiting interradial crassitude and a foveolate sculpture.

Foveo about $1 \mu \mathrm{m}$ in diameter.

Infraturma CINGULATI Potonié \& Klaus emend. Dettmann 1963

Genus Contignisporites Dettmann 1963
Genus Contignisporites comprises cingulate spores with a bilateral symmetrical murornate sculptured distal side and a radial symmetrical murornate sculptured proximal side.

Contignisporites dunrobinensis (Couper 1958) Schulz 1967

Plate 3, fig. 9.

Contignisporites problematicus (Couper 1958) Döring 1965

Plate 3, fig.8.

C. problematicus is distinguished from $C$. dunrobinensis by a smaller overall size $(30-40 \mu \mathrm{m})$ and a more delicate sculpture.

Genus Densoisporites Weyland \& Krieger 1953 emend. Dettmann 1963

Densoisporites velatus Weyland \& Krieger 1953 Plate 3, fig. 11.

Genus Heliosporites Schulz 1962

Heliosporites reissingeri (Harris 1957) Chaloner 1969

Plate 3, fig. 12.

$H$. reissingeri is characterized by a central body enveloped in a loosely attached spinose outer exine.

H. altmarkensis Schulz 1962 is a junior synonym of $H$. reissingeri.

\section{Genus Perotrilites Couper 1953}

Perotrilites sp.

Plate 3, fig. 13.

Perotrilites sp. includes trilete subcircular to triangular spores with distinct sutures and a central body enveloped by an outer exinelayer. The overall size $(25-30 \mu \mathrm{m})$ is smaller than previously described Perotrilites types (Couper 1953, Schulz 1966, Guy 1971).

Genus Platyptera Naumova

Cf. Platyptera triloba Naumova

Plate 3, fig. 16.

Only a single specimen was recovered. It differs from $P$. triloba by lacking radial sculpture, and from P. trilingua (Horst) Schulz sensu Guy 1971 by the lack of radial crassitude.

Cf. $P$. triloba is perhaps a reworked carboniferous spore. 

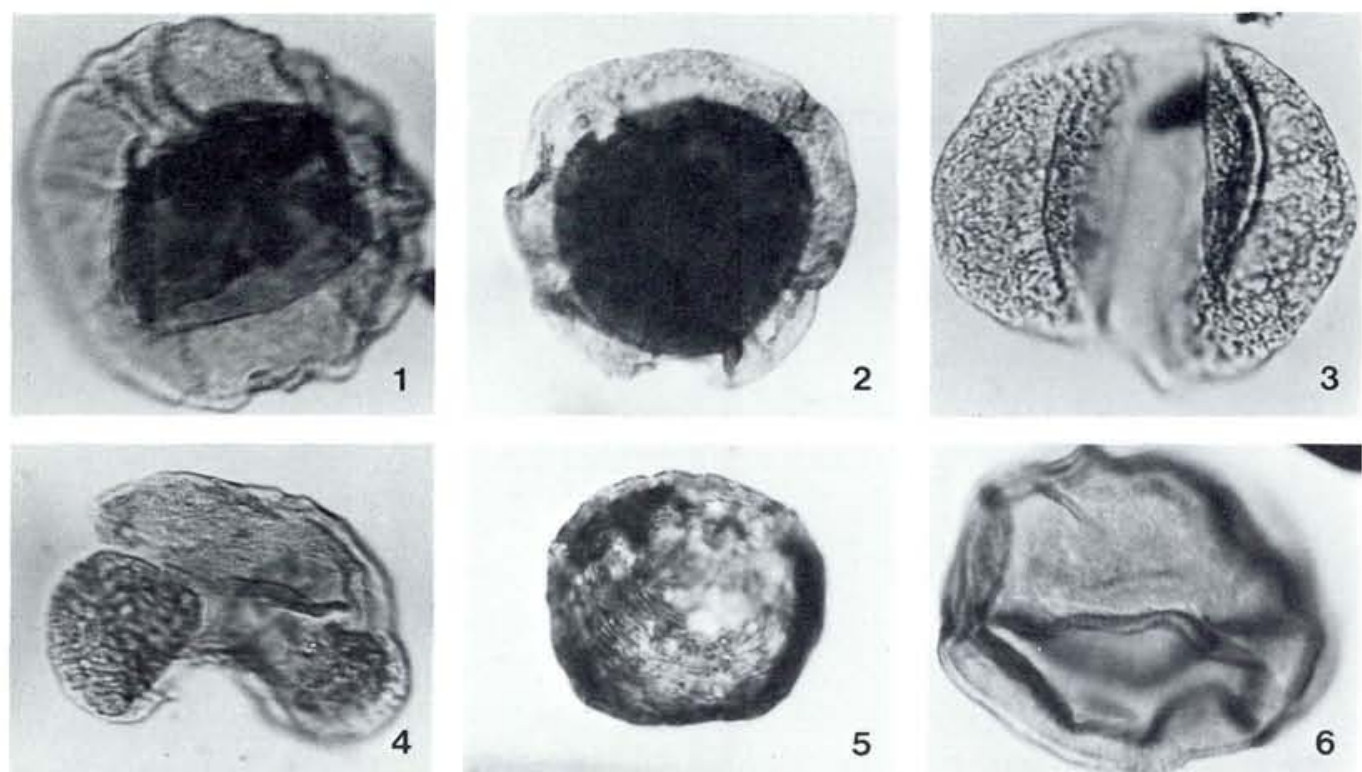

5
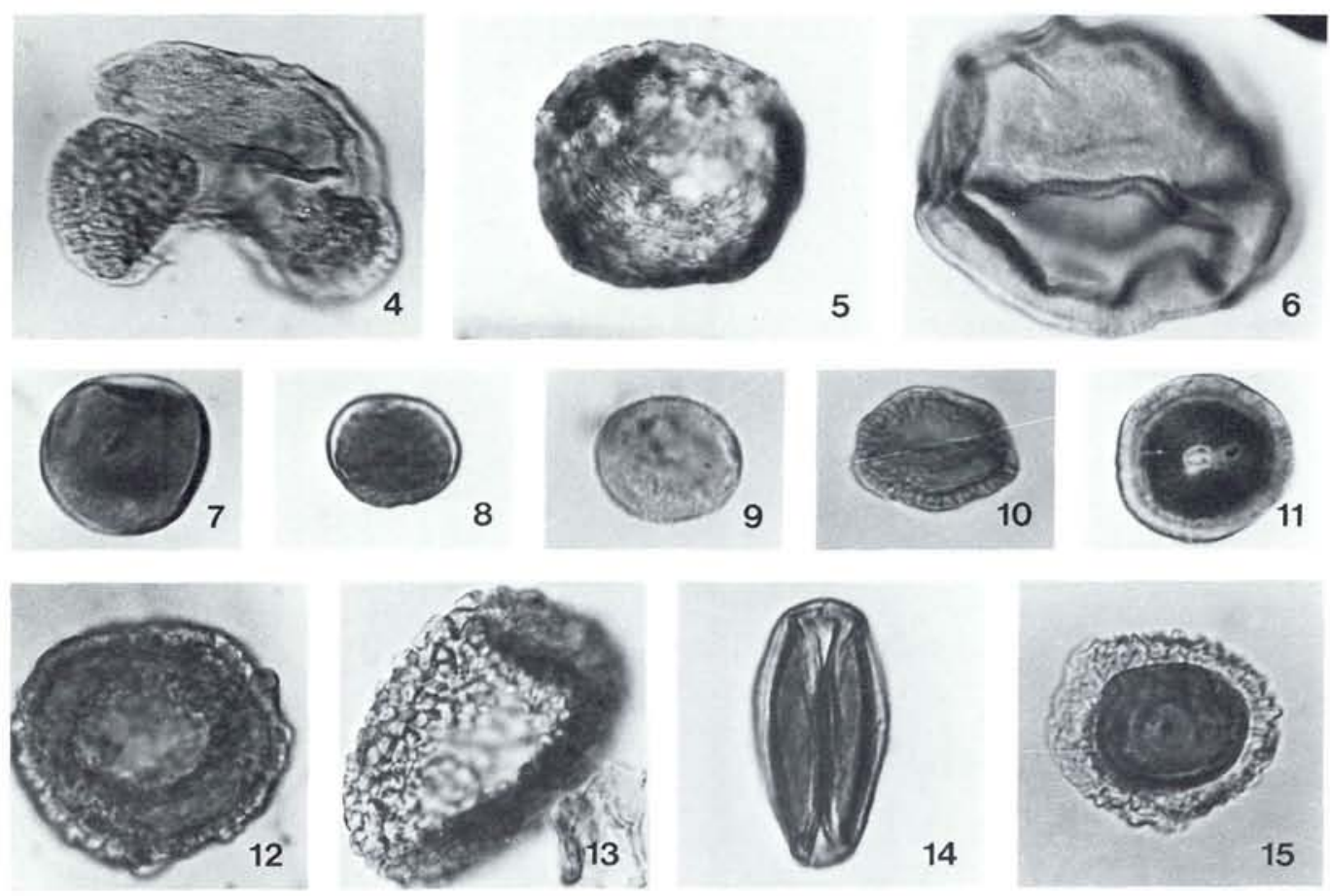

14
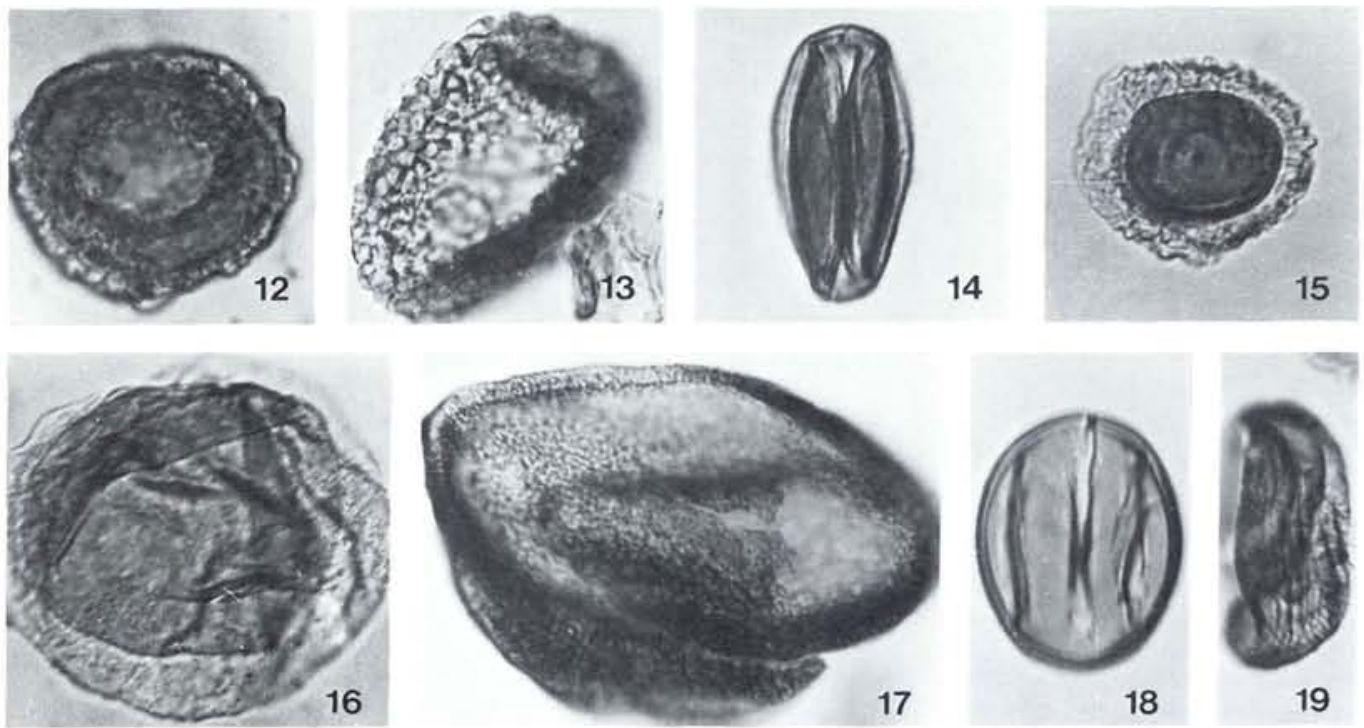

Plate 4.

Fig.1; Callialasporites turbatus, fig. 2; Cf. Callialasporites microvelatus, fig. 3 ; Alisporites robustus, fig. 4: Pityosporites scaurus, fig. 5 ; Chomotriletes minor, fig. 6; A raucariacites australis, fig. 7; Spheripollenites psilatus, fig. 8; Spheripollenites scabratus, fig. 9; Spheripollenites subgranulatus, fig. 10; Clavatipollenites hughesii, fig. 11; Corollina meyeriana fig. 12; Cerebropollenites macroverrucosus, fig. 13; Cerepollenites thiergartii, fig. 14; Cycadopides nitidus, fig. 15; Perinopollenites cf. elatoides, fig. 16; Perinopollenites elatoides, fig. 17: Chasmatosporites magnolioides, fig. 18; Eucommiidites troedssonii, fig. 19; Corollina torosus. 
Turma MONOLETES Ibrahim

Subturma AZONOMONOLETES Luber

Infraturma PSILAMONOLETI Van der Hammen

Genus Laevigatisporites Ibrahim

1956: Monolites Cookson ex Potonié

Laevigatosporites mesozoicus Schulz 1967

Plate 3, fig. 17.

Spore monolete with $1,5-2,5 \mu \mathrm{m}$ thick, laevigate exine. Length $45-55 \mu \mathrm{m}$.

Genus Marattisporites Couper 1958

Marattisporites scabratus Couper 1958

Plate 3, fig. 14.

Anteturma POLLENITES Potonié

Turma SACCITES Erdtman 1947

Subturma MONOSACCITES (Chitalay) Potonié \& Kremp 1954

Genus Callialasporites Dev 1961

1961 March: Callialasporites Dev

1961 Dec.: Applanopsis Döring

1970: Callialasporites Dev - Pocock

Callialasporites minus (Traulau 1968) Guy 1971

Plate 3, fig. 19.

Monosaccate pollen with circular to subcircular amb and a two layered exine. Outer layer forming a 5-6 $\mu \mathrm{m}$ broad and radial folded equatorial saccus.

Callialasporites dampieri (Balme 1957) Dev 1961

Similar to $C$. minus apart from the size, larger than $55 \mu \mathrm{m}$.

Callialasporites turbatus (Balme 1957) Schulz 1967

Plate 4, fig. 1.

Amb subcircular to subtriangular, central body distinct triangular, saccus seldom folded.

Cf. Callialasporites microvelatus Schulz 1967

Plate 4, fig. 2.

Cf. $C$. microvelatus is distinguished from $C$. microvelatus by a wider equatorial saccus, $6-8 \mu \mathrm{m}$.

\section{Subturma DISACCITES Cookson}

Genus Quadraeculina Malyavkina 1949 sensu Schuurman 1977
Quadraeculina anellaeformis Malyavkina 1949

Plate 3, Fig. 18.

Genus Vitreisporites Leschik 1955 emend. Jansonius 1962

1958: Caytonipollenites Couper

Vitreisporites pallidus (Reissinger 1950) Nilsson 1958

Plate 3, fig. 15.

$V$. pallidus is characterized by its small dimensions. Length $\times$ breadth about $15 \times 30 \mu \mathrm{m}$, Exine less than $1 \mu \mathrm{m}$ thick.

Genus Pityosporites Seward emend. Manum 1960

Pityosporites scaurus (Nilsson 1958) Schulz 1967 Plate 4, fig. 4.

Sacci strongly distally placed. Attachment to central body not accompanied by folds. Breadth 45-55 $\mu \mathrm{m}$.

Genus Protopinus Bolkhovitina

Protopinus scanicus Nilsson 1958

A large dimension, thin exine and small difference in sculpture between the central body and the sacci distinguish $P$. scanicus from other bisaccate pollen.

Genus Alisporites Daugherty emend. Nilsson 1958

Alisporites robustus Nilsson 1958

Plate 4, fig. 3.

The species has distinct folds distally at the sacci attachment.

Turma ALETES Ibrahim

Genus Spheripollenites Couper 1958

Spheripollenites psilatus Couper 1958

Plate 4, fig. 7.

Spheripollenites scabratus Couper 1958

Plate 4, fig. 8.

Spheripollenites subgranulatus Couper 1958

Plate 4. fig. 9.

Genus Chomotriletes Naumova ex Naumova

Chomotriletes minor (Kedves) Pocock 1970

Plate 4, fig. 5 
Spore alete with circular amb. Exine about 1,5 $\mu \mathrm{m}$ thick and sculptured with concentric ribs. Dimension $20-40 \mu \mathrm{m}$.

\section{Genus Perinopollenites Couper 1958}

Perinopollenites elatoides Couper 1958

Plate 4, fig. 16

Perinopoolenites cf. elatoides (Couper 1958)

Lund 1977

Plate 4, fig. 15

Apart from a thicker inner exine and a folded outer exine similar to $P$. elatoides.

\section{Genus Araucariacites Cookson 1947 ex Couper} 1953

Araucariacites australis Cookson 1947

Plate 4, fig. 6 .

\section{Genus Cerebropollenites Nilsson 1958}

Cerebropollenites macroverrucosus (Thiergart 1949) Schulz 1967

Plate 4, fig. 12.

1958: Cerebropollenites mesozoicus Schulz 1967

Cerebropollenites thiergartii Schulz 1967

Plate 4, fig. 13.

C. thiergartii is distinguished from $C$. macroverrucosus by a dense and distinct verrucate sculpture. Verrucae 1-3 $\mu \mathrm{m}$ broad and 1-2 $\mu \mathrm{m}$ high.

Turma PLICATES (Naumova) Potonié 1960

Subturma MONOCOLPATES Iversen \& TroelsSmith

Genus Chasmatosporites Nilsson 1958 emend. Pocock \& Jansonius 1969

Chasmatosporites magnolioides (Erdtman 1948)

Nilsson 1958 sensu Morbey 1975

Plate 4, fig. 17.

Pollen monocolpate with subcircular to oval amb. Exine vermiculate structured and about 2 $\mu \mathrm{m}$ thick.

Genus Cycadopides Wodehouse ex Wilson \& Webster

Cycadopides nitidus (Balme 1957) Pocock 1970 sensu lato Tralau 1968

Plate 4, fig. 14.
Tralau 1968: Ginkgocycadophytus nitidus (Balme 1957) De Jersey 1962

\section{Genus Clavatipollenites Couper 1958}

Clavatipollenites hughesii Couper 1958

Plate 4, fig. 10.

Pollen monocolpate with more or less oval amb. Exine less than $2 \mu \mathrm{m}$ thick and infrareticulate.

Subturma PRAECOLPATES Potonié \& Kremp 1954

Genus Eucommiidites Erdtman 1948 emend. Scheuring 1970

Eucommiidites troedssonii Erdtman 1948

Plate 4, fig. 18.

Turma POROSES (Naumova) Potonié 1960

Subturma MONOPORINES Naumova

Genus Corollina Malyavkina 1949 emend. Cornet \& Traverse 1975

1953: Classopollis Pflug

Corollina torosus (Reissinger 1950) Klaus 1960 emend. Cornet \& Traverse 1975

Plate 4, fig. 9.

Corollina meyeriana (Klaus 1960) Venkatachala

\& Goćzán 1964

Plate 4, fig. 11.

Acknowledgements. The author wishes to thank Kurt Jakobsen (Ribe) and Pia E. Hoelstad (Copenhagen) for field-work assistance. Kaj Raunsgaard Pedersen (Århus) and Else Marie Friis (Århus) are thanked for valuable discussions, much help and critical reading of the manuscript. Dorothy Guy-Ohlson (Stockholm) and Hans Christian Enevoldsen (Copenhagen) kindly improved the English text.

\section{Dansk sammendrag}

Et 103 meter mægtigt afsnit af Bagå Formationen på Bornholm er beskrevet lithologisk og undersøgt palynologisk.

70 spore/pollen morfo-typer er iagttaget og behandlet systematisk. Specielt er morfo-slægterne Deltoidospora, Tripartina, Manumia og Lycopodiumsporites indgående behandlet. Desuden er diagnosen for Manumia variverrucata emenderet.

Baseret på de palynologiske data er det muligt at opstille 3 biozoner. Grænsen mellem de to nederste biozoner kan ved korrelation til ammonitzonerede lagserier i England, Holland og DDR bestemmes til gransen mellem Nedre Jura og Mellem Jura. Dette, samt sammenligninger med undersøgelser i Skåne, daterer det undersøgte profil af Bagå Formationen til Sen Toar- 
cian - Mellem Jura. En nærmere øvre afgrænsning kan på nuværende tidspunkt ikke udpeges.

Udfra lithologien samt det totale fravær af marine palynomorpher foreslås flodslettemiljøet som det fremherskende. Den regressive natur af Bagå Formationen bekræftes af udpræget tendens til grovere sedimenter $i$ de yngste afsnit, således ses mudderstrømme stammende fra alluvialkeglemiljøet øverst i profilet.

\section{References}

Balme, B. E. 1957: Spores and pollen grains from the Mesozoic of Western Australia. Coal Res. C.S.I.R.O. Ref. T. C. 25 : $1-48$.

Bartholin, C. T. 1892: Nogle i den bornholmske Juraformation forekommende Planteforsteninger. Botan. Tidsskr. 18: 1228.

Bartholin, C. T. 1894: Nogle i den bornholmske Juraformation forekommende Planteforsteninger. Botan. Tidsskr. 19: 87115.

Bertelsen, F. 1974: Palynological investigations of the TriassicJurassic section of the Hobro No. 1 borehole. In Michelsen, O. 1978: Report on the Jurassic of the Hobro No. 1 and Voldum No. 1 borings, Denmark. Danm. geol. Unders. Arbog 1978: 141-149.

Burger, D. 1966: Palynology of the uppermost Jurassic and lowermost Cretaceous strata in the Eastern Netherlands. Leidse geologische Mededelingen. 35: 209-276.

Chaloner, W. G. 1969: Triassic spores and pollen. In Tschudy, R. H. \& Scott, R. A. (eds): Aspects of palynology. WileyInterscience: New York, 291-309.

Chang, L. C. 1965: Pollen assemblages and their significance in the Yima coalbearing series from Yinchi Hsien, Honan Province. In Kremp. G. O. W., Traverse, A. \& Sprackman, W. (eds.) 1967: Catalog of fossil spores and pollen, vol. 26. University Park: Pennsylvania, 1-4.

Cookson, I. C. 1953: Difference in miospore composition of some samples from a bore at Comaun, South Australia. Aust. J. Bot. 1, 3: 462-473.

Cornet, B. \& Traverse, A. 1975: Palynological contributions to the chronology and stratigraphy of the Hartford Basin in Connecticut and Massachusetts. Geoscience and Man 11: 1-33.

Couper, R. A. 1953: Upper Mesozoic and Cainozoic spores and pollen grains from New Zealand. New Zealand Geol. Surv., Palaeontological bull. 22: 1-77.

Couper, R. A. 1958: British Mesozoic microspores and pollen grains. A systematic and stratigraphic study. Palaeontographica Abt. B. 103, 4-6: 75-179.

Danzé-Corsin, P. \& Laveine, J. P. 1963: Microflore. In Briche, P., Danzé-Corsin, P. \& Laveine, J. P.: Flore infraliasique du Boulonais (macro- et microflore). Men. Soc. Geol. Nord. 13: 57-109.

Delcourt, A. \& Sprumont, G. 1955: Les spores et grains de pollen du Wealdien du Hainaut. Mém. Soc. Belge. Géol. Paléont. Hydrol. 4, 5: 1-73.

Dettmann, M. E. 1963: Upper Mesozoic microfloras from South-Eastern Australia. Proc. Roy. Soc. Victoria n.s. 77, 1: $1-148$.

Dev, S. 1961: The fossil flora of the Jabalpur Series - 3. Spores and pollen grains. Palaeobotanist. 8, 1-2: 43-56.

Döring, H. 1965: Die sporenpaläontologische Gliederung des Wealden in Westmecklenburg (Struktur Werle). Geologie, Beiheft 47: 1-118.

Döring, H., Krutzsch, W., Mai, D. H. \& Schulz, E. 1963: Retitriletes. In Krutzsch, W. 1963: Atlas der mittel- und jung- tertiären Sporen- und Pollen-sowie der Mikroplanktonformen des nördlichen Mitteleuropas. Lief II. VEB Deutscher Verlag der Wissenschaften: Berlin, 8-18.

Döring, H., Krutzsch, W., Schulz, E. \& Timmermann, E. 1966: Über einige neue Subformgenera der Sporengattung Stereisporites TH. \& PF. aus dem Mesozoikum und Alttertiär Mitteleuropas. Geologie, Beiheft 55: 72-89.

Erdtman, G. 1948: Did Dicotyledonous Plants exist in Early Jurassic Times? Geol. Fören. Stockh. Förh. 70, 2: 265-271.

Erve, A. W. van 1977: Palynological investigation in the Lower Jurassic of the Vicentinian Alps (NE-Italy). Rev. Palaeobot. Palynol. 23: 1-117.

Filatoff, J. 1975: Jurassic palynology of the Perth Basin, Western Australia. Palaeontographica Abt. B. 154, 1-4: 1-113.

Florin, R. 1958: On Jurassic Taxads and Conifers from NorthWestern Europe and Eastern Greenland. Acta Horti Bergiani. 17, 10: 257-402.

Forchhammer, G. 1837: Om de Bornholmske Kulformationer. Vid. Sel.Naturvid. \& Mathem. Afh. 7: 64 pp.

Graff-Pedersen, P. 1961: Lermineralogien $i$ de limniske jurasedimenter på Bornholm. Doctoral thesis. University of Copenhagen: 1-149.

Graff-Pedersen, P. \& Bondam, J. 1963: Hasle klinkerfabrik Clay Pit and Rabække Clay Pit. Int. Clay Conf. Field Trip C.: 19 pp.

Gravesen, R., Rolle, F. \& Surlyk, F. 1982: Lithostratigraphy and sedimentary evolution of the Triassic, Jurassic and Lower Cretaceous of Bornholm, Denmark. Danm. Geol. Unders. Ser. B. 7: 1-51.

Gry, H. 1951: Kullagene ved Hasle på Bornholm og deres tektonik. Meddr dansk geol. Foren. 12: 172-173.

Gry, H. 1969: Megaspores from the Jurassic of the island of Bornholm, Denmark. Meddr dansk geol. Foren. 19: 69-89.

Grönwall, K. A. 1899: Bemærkninger om Bornholms sedimentare dannelser og deres tektoniske Forhold. Danm. Geol. Unders. II rk. 10: 1-48.

Guy, D. J. E. 1971: Palynological investigations in the Middle Jurassic of the Wilhelmsfält boring, Southern Sweden. Publ. Inst. Min. Palaeont. Quatern. Geol. Lunds Univ. 168: $1-104$

Guy-Ohlson, D. 1978: Jurassic biostratigraphy of three borings in NW Scania (A brief palynological report). Sver. Geol. Unders. Rapp. Medd. 11: 1-29.

Guy-Ohlson, D. 1981: Rhaeto-Liassic palynostratigraphy of the Valhall bore No. 1, Scania. Geol. Fören. Stockh. Förh. 103, 2: 233-248.

Hansen, K. 1939: Oversigt over de bornholmske Juradannelsers Stratigrafi og Tektonik. Meddr dansk geol. Foren. 9: 459-481.

Harris, T. M. 1937: The fossil flora of Scoresby Sound, East Greenland. Part 5: Stratigraphic relations of the Plant Beds. Meddr Grønland. 112, 2: 114 pp.

Harris, T. M. 1957: A Liassic-Rhaetic flora in south Wales. Proc. Roy. Soc. Lond. 147, B: 289-308.

Hedberg, H. D. 1972: Summary of an international guide to stratigraphic classification, terminology and usage. Lethaia. 5: 297-323.

Herngreen, G. F. W. \& Boer, K. F. de 1974: Palynology of Rhaetian, Liassic and Dogger strata in eastern Netherlands. Geol. en Mijnbouw. 53, 6: 343-368.

Höhne, R. 1933: Beiträge zur Stratigraphie, Tektonik und Paläogeographi des südbaltischen Rhät-Lias, insbesondere auf Bornholm. Abh. Geol.-Pal. Inst. Griefswald. 12: 105 pp.

Jansonius, J. 1962: Palynology of Permian and Triassic sediments, Peace River Area, Western Canada. Palaeontographica Abt. B. 110, 1-4: 35-98.

Jersey, N. J. de 1962: Triassic spores and pollen grains from the Ipswich coalfield. Geological Survey of Queensland. 307: 1-18. 
Jespersen, M. 1865: Liden geognostisk Veiviser paa Bornholm. Rønne. $67 \mathrm{pp}$.

Jespersen, M. 1866: En Skitse af Sorthat Kulværk paa Bornholm. Indbydelsesskrift til de offentlige Examina i Rönne Höiere Realskole: 5-38.

Kedves, M. \& Simoncsics. P. 1964: Microstratigraphy of the carbonate manganese ore layers of the shaft III of Úrkút on the basis of palynological investigations. Acta Univ. Szeged., Acta Mineral.-Petro. 16: 2-48.

Klaus, W. 1960: Sporen der Karnischen Stufe der ostalpinen Trias. Jb. Geol. Bundesanstalt (Wien) Sonderbd. 5: 107184.

Krutzsch, W. 1959: Mikropaläontologische (sporenpaläontologische) Untersuchungen in der Braunkohle des Geiseltales. Beiheft z. Geologie. 21-22: 1-435.

Krutzsch, W. 1963: Atlas der mittel- und jungtertiären Sporenund Pollen-sowie der Mikroplankionformen des nördlichen Mitteleuropas. Lief. II, III. VEB Deutscher Verlag der Wissenschaften: Berlin, 141 pp., 128 pp.

Krutzsch, W. 1967: Atlas der mittel und jungtertiären Sporenund Pollen-sowie der Mikroplanktonformen des nördlichen Mitteleuropas. Lief. IV/V. VEB Deutscher Verlag der Wissenschaften: Berlin, 232 pp.

Leschik, G. 1955: Die Keuperflora von Neuewelt bei Basel. II. Die Iso- und Mikrosporen. Schweiz. Palaeont. Abh. 72, $1-70$.

Levet-Carette; J. 1964: Étude de la microflore bajocienne d'un sondage effectué dans les sous-sol de Boulogne-sur-Mer (Pas-de Calais). Soc. géol. Nord. Annls. 84, 2: 91-121.

Lund; J. J. 1977: Rhaetic to Lower Liassic palynology of the onshore south-eastern North Sea Basin. Danm. Geol. Unders., II rk. 109: 1-129.

Malling, C. 1920: Foredrag om den marine Lias og WealdenAflejringer paa Bornholm. Meddr dansk geol. Foren. 5: 55-57.

Malling, C. \& Grönwall, K. A. 1909: En Fauna i Bornholms Lias. Meddr dansk geol. Foren. 15: 271-316.

Malyavkina, V. S. 1949: Index of spores and pollen; JurassicCretaceous. In Traverse, A. \& Sprackman, W. (eds.) 1974-76: Catalog of fossil spores and pollen, vol. 38, 39, 40. University Park: Pennsylvania, 227 pp., 243 pp., 1107.

Malyavkina, V. S. 1953: Upper Triassic, Lower Jurassic and Middle Jurassic spore-pollen complexes of eastern and western Pre-Urals. In Traverse, A. \& Sprackmann, W. (eds.) 1976: Catalog of fossil spores and pollen. vol. 40. University Park: Pennsylvania, 108-219.

Malyavkina, V. S. 1964: In Jansonius, J. \& Hills, L. V. 1976: Genera file of fossil spores and pollen. Special publication, Department of Geology, Univ. of Calgary, Can. Card no. 3039.

Manum, S. 1960: On the Genus Pityosporites Seward 1914. Nytt Mag. Bot. 8: 11-15.

Miner, E. L. 1935: Paleobotanical examinations of Cretaceous and Tertiary coals. Am. Midl. Nat. 16:585-625.

Morbey, S. J. 1975: The palynostratigraphy of the Rhaetian stage, Upper Triassic in the Kendelbachgraben, Austria. Palaeontographica Abt. B. 152, 1-3: 1-75.

Mädler, K. 1964: Die geologische Verbreitung von Spores und Pollen in der Deutschen Trias. Beiheft Geol. Jahrb. 65: 147 pp.

Möller, H. 1902: Bidrag till Bornholms Fossila Flora. Pteridofyter. Lunds Univ. Arsskr. Afd. 2. 38: 63 pp.

Möller, H. 1903: Bidrag till Bornholms Fossila Flora (Rhät och Lias). Gymnospermer. Kgl. Svenska Vidensk. Akad. Hand. 36, 6: $56 \mathrm{pp}$.

Nilsson, T. 1958: Über das Vorkommen eines mesozoischen Sapropelgesteins in Schonen. Lunds Univ. Arsskr. N. F. Afd. 2. 54: $112 \mathrm{pp}$.
Pedersen, K. R. \& Lund, J. J. 1980: Palynology of the plantbearing Rhaetian to Hettangian Kap Steward Formation, Scoresby Sund, East Greenland. Rev. palaeobot. Palynol. 31: $1-69$.

Pflug, H. D. 1953: Zur Entstehung und Entwicklung des Angiospermiden Pollens in der Erdgeschichte. Palaeontographica Abt. B. 95, 4-6: 60-171.

Playford, G. \& Dettmann, M. E. 1965: Rhaeto-Liassic plant microfossils from the Leigh Creek coal measures, South Australia. Senkenbergiana leth. 46: 127-181.

Pocock, S. A. J. 1962: Microfloral analysis and age determination of strata at the Jurassic-Cretaceous boundary in the western Canada plains. Palaeontographica Abt. B. 111, 1-3: 1-95.

Pocock, S. A. J. 1970: Palynology of the Jurassic sediments of western Canada. Part 1. Terrestrial species. Palaeontographica Abt. B. 130: 12-136.

Pocock, S. A. J. \& Jansonius, J. 1969: Redescription of some fossil gymnospermous pollen (Chasmatosporites, Marsupipollenites and Ovalipollis). Can. J. Botany. 47: 155-165.

Potonié, R. 1956: Synopsis der Gattungen der Sporae dispersae. I Teil: Sporites. Beiheft Geol. Jahrb. 23: 1-103.

Potonié, R. 1960: Synopsis der Gattungen der Sporae dispersae. III Teil: Nachträge Sporites, Fortsetzung Pollinites. Mit Generalregister zu Teil I-III. Beiheft Geol. Jahrb. 39: 1-189.

Potonié, R. \& Kremp, G. 1954: Die Gattungen der paläozoischen Sporae dispersae und ihre Stratigraphie. Geol. Jahrb. 69: 111-194.

Reissinger, A. 1950: Die "Pollenanalyse" ausgedehnt auf alle Sedimentgesteine der geologischen Vergangenheit. Zweiter Teil. Palaeontographica Abt. B. 90, 4-6: 99-126.

Rosenkrantz, A. 1939: Bidrag til de danske Juraaflejringers stratigrafi. Meddr dansk geol. Foren. 9: 526-528.

Rouse, G. E. 1959: Plant microfossils from Kootenay coalmeasures strata of British Columbia. Micropaleontology. 5, 3: 303-325.

Rørdam, K. 1890: Undersøgelse af mesozoiske Lerarter og Kaolin paa Bornholm i geologisk og teknisk Henseende. Danm. geol. Unders. II rk. 1: 1-109.

Scheuring, B. W. 1970: Palynologische und palynostratigraphische Untersuchungen des Keupers im Bölchentunnel (Solothurner Jura). Schweiz. paläont. Abh. 88: 1-119.

Schulz, E. 1962: Sporenpaläontologische Untersuchungen zur Rhät- Lias Grenze im Thüringen und der Altmark. Geologie. 11, 3: 308-319.

Schulz, E. 1966: Über einige Sporae dispersae aus dem älteren Mesophyticum Deutschlands Beiheft z. Geologie. 55: 130151.

Schulz, E. 1967: Sporenpaläontologische Untersuchungen rätoliassischer Schichten im Zentralteil des Germanischen Beckens. Paläont Abh. B. 2, 3: 542-633.

Schulz, E. 1970: Die Sporen der Gattungen Stereisporites Thomson \& Pflug 1953 aus dem älteren Mesophyticum des Germanischen Beckens. Paläont. Abh. B. 3, 3-4: 683-719.

Schuurman, W. M. L. 1977: Aspects of Late Triassic palynology. 2. Palynology of the "Grés et Schiste á Avicula contorta" and "Argiles de Levallois" (Rhaetian) of north-eastern France and southern Luxemburg. Rev. Palaeobot. Palynol. 23: 159-253.

Thiergart, F. 1949: Der stratigraphische Wert mesozoischer Pollen und Spores. Palaeontographica Abt. B. 89: 1-34.

Thomson, P. W. \& Pflug, H. 1953: Pollen und Spores des mitteleuropäischen Tertiärs. Palaeontographica Abt. B. 94, 1-4: 1-138.

Tralau, H. 1968: Botanical investigations into the fossil flora of Eriksdal in Fyledalen, Scania. II: The Middle Jurassic microflora. Sver. geol. Unders. Ser. C. 633: 1-185. 
Traverse, A. \& Sprackman, W. 1976: Catalog of fossil spores and pollen vol. 40. University park: Pennsylvania, $243 \mathrm{pp}$.

Venkatachala, B. S. \& Góczán, F. 1964: The spore-pollen flora of the Hungarian "Kössen facies". Acta Geol. Acad. Sci. Hungary. 8: 203-228.
Weyland, H. \& Krieger, W. 1953: Die Sporen und Pollen der Aachener Kreide und ihre Bedeutung für die Charakterisierung des Mittleren Senons. Palaeontographica Abt. B. 95: 6-29. 